\title{
The Medieval Globe
}

Volume 2

Number 2 Legal Worlds and Legal Encounters

Article 9

$12-23-2016$

\section{Chinese Porcelain and the Material Taxonomies of Medieval Rabbinic Law: Encounters with Disruptive Substances in Twelfth- Century Yemen}

\author{
Elizabeth Lambourn \\ De Montfort University, ELambourn@dmu.ac.uk \\ Phillip I. Ackerman-Lieberman \\ Vanderbilt University, phil.lieberman@vanderbilt.edu
}

Follow this and additional works at: https://scholarworks.wmich.edu/tmg

Part of the Ancient, Medieval, Renaissance and Baroque Art and Architecture Commons, Classics Commons, Comparative and Foreign Law Commons, Comparative Literature Commons, Comparative Methodologies and Theories Commons, Comparative Philosophy Commons, Medieval History Commons, Medieval Studies Commons, and the Theatre History Commons

\section{Recommended Citation}

Lambourn, Elizabeth and Ackerman-Lieberman, Phillip I. (2016) "Chinese Porcelain and the Material Taxonomies of Medieval Rabbinic Law: Encounters with Disruptive Substances in Twelfth-Century Yemen," The Medieval Globe: Vol. 2 : No. 2 , Article 9.

Available at: https://scholarworks.wmich.edu/tmg/vol2/iss2/9

This Article is brought to you for free and open access by the Medieval Institute Publications at ScholarWorks at WMU. It has been accepted for inclusion in The Medieval Globe by an authorized editor of ScholarWorks at WMU. For more information, please contact wmuscholarworks@wmich.edu.

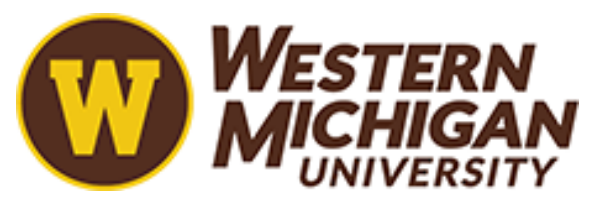




\section{THE \\ MEDIEVAL \\ GLOBE}

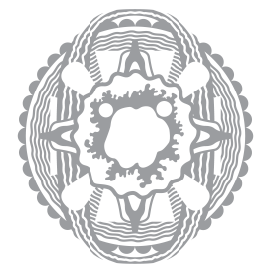

Volume 2.2 | 2016

ARChumanities press 
Copyeditor

Shannon Cunningham

Editorial Assistant

Kelli McQueen

Page design and typesetting

Martine Maguire-Weltecke

\section{(c) 2016, Arc Humanities Press, Kalamazoo and Bradford}

(c) $\odot \$$ This work is licensed under a Creative Commons Attribution-

NonCommercial-NoDerivatives 4.0 International Licence.

The authors assert their moral right to be identified as the authors of their part of this work.

Permission to use brief excerpts from this work in scholarly and educational works is hereby granted provided that the source is acknowledged. Any use of material in this work that is an exception or limitation covered by Article 5 of the European Union's Copyright Directive (2001/29/EC) or would be determined to be "fair use" under Section 107 of the U.S. Copyright Act September 2010 Page 2 or that satisfies the conditions specified in Section 108 of the U.S. Copyright Act (17 USC §108, as revised by P.L. 94-553) does not require the Publisher's permission.

ISSN 2377-3561 (print)

ISSN 2377-3553 (online)

www.arc-humanities.org 


\title{
CHINESE PORCELAIN AND THE MATERIAL TAXONOMIES OF MEDIEVAL RABBINIC LAW: ENCOUNTERS WITH DISRUPTIVE SUBSTANCES IN TWELFTH-CENTURY YEMEN
}

\author{
ELIZABETH LAMBOURN and PHILLIP ACKERMAN-LIEBERMAN
}

LEGAL TEXTS ARE increasingly proving to be valuable sources for the study of the material culture of the medieval Middle East and the Islamicate world more broadly. Innovative monographs (such as Leor Halevi's Muhammad's Grave: Death Rites and the Making of Islamic Society) and articles (such as Tziona Grossmark's study of glass within Jewish law and Ruba Kana'an's use of Islamic legal sources in the interpretation of medieval metalwork production) exemplify the new perspectives that emerge from the dialogue between legal texts and material things. ${ }^{1}$ As Don Davis proposes in this issue, we can see the "story of law" as "the formation of endless practical legal arrangements, the creation of rules and categories to tame them, and the subsequent mutual development of (and tension between) both as an ongoing encounter." ${ }^{2}$ Hence, the objects of material culture offer us a new opportunity to explore the encounter between the theory and the praxis of law. Nevertheless, the slow pace at which legal corpora are being integrated into the study of material culture is a symptom of the complexity of these sources and the fundamentally interdisciplinary and collaborative nature of such an enterprise. ${ }^{3}$

This article focuses on a set of legal questions about șinī vessels (literally, "Chinese" vessels) sent from the Jewish community in Aden to Fustat (Old Cairo) in the mid-1130s CE. These questions survive in a memorandum subsequently deposited in the so-called Cairo Geniza, a document which eventually made its way to Cambridge University Library (see Figure 5). ${ }^{4}$

\footnotetext{
I Finbarr Barry Flood's forthcoming transhistorical exploration of the "prohibition of images" (Bilderverbot) as a perceived characteristic of Islamic cultures also innovatively integrates legal sources into this debate (the study's working title is Islam and Image: Polemics, Theology, and Modernity). Hisba manuals (compilations of marketplace rules) are exceptionally rich, if complex to interpret.
}

2 Davis, “Toward a History of Documents," 169-170.

3 Ghabin's Hisba: Arts and Craft in Islam illustrates the problems of interpreting terms and technologies described in hisba texts without a very sharply defined geographical, historical, and material context.

4 Goitein and Friedman, India Traders, 387, lines 5-12. In Goitein's classification, the letter is designated as document II, 33-34, and is composed of two surviving fragments, T-S 8J37.1 
While șiñi vessels are listed in various Geniza inventories and wills, this is the only known discussion of the materiality of sini to occur in any Geniza document, and also the earliest dated and localized query about these vessels' status with respect to Jewish law of vessels used for food consumption. ${ }^{5}$ Although opaque at first reading, our analysis of these queries will suggest that their phrasing and timing can be linked to the contemporaneous appearance, in the Yemen, of a new type of Chinese ceramic material: in effect, an early true "porcelain.." Although various types of Chinese ceramic had been entering the Middle East since the first half of the ninth century, sometimes in huge quantities, this particular ceramic fabric presented Jewish scholars and householders at the port of Aden with a perplexing problem, since its properties confounded their expectations of how a ceramic fabric should look, feel, and behave. In particular, the notable translucency of these early porcelains raised issues of purity (tahora) and uncleanness (tuma) that were fundamental to proper Jewish ritual observance: concepts that were structured by complex material taxonomies. By confounding and destabilizing these taxonomies,

and T-S Ar. 5.2; for the English translation of the full letter with footnotes and commentary, see Ibid., 377-89. The Hebrew edition of the letter includes the full transcription of the Judaeo-Arabic original and can be found in Goitein and Friedman, Madmūn ha-Nagid, 234-48 (for the Judaeo-Arabic transcription of this passage see page 239, lines 5-12). The document is also reproduced, with the text of the Judaeo-Arabic original and a Hebrew translation, in Goitein and Friedman, Halfon ha-soher, 119-25.

5 See various references to șinī in Goitein's Mediterranean Society (given in the cumulative indexes in volume 6 under "porcelain" and "șin̄"). To date, we have only been able to identify possible evidence for one earlier discussion of șinī vessels: see below, n. 7 .

6 A European invention of the fourteenth century, the term "porcelain" bears no relationship to emic Chinese ceramic categories; however, it is commonly used even by specialists of Chinese ceramics to refer to high-fired ceramics with exceptionally hard, vitreous bodies: this is the sense of the term employed here. Regina Krahl notes that "in the West, the term 'porcelain' is reserved for ceramics that are white, translucent and resonant and are fired at temperatures above 1,300 degrees Celsius," whereas in China there was no distinction made between these fabrics and so-called stonewares, ceramics that can lack these characteristics and are only fired above 1,200 degrees Celsius. As she observes, "in practice there is no distinct dividing line between the two but a smooth transition, and the difference is not necessarily apparent to the naked eye" (Krahl, "White Wares of Northern China," 202). The term "porcellaneous" is often used to reflect this complexity. Technically speaking, the earliest porcelains were produced in China in Henan, at the Gongxian kilns, in the seventh century; while Jingdezhen in the south began producing early porcelains in the late Tang/Five Dynasties period (907-60 CE): see Needham, Kerr, and Wood, Science and Civilization in China, 151-53 and 216-19; see also Pierson, "Industrial Ceramics in China," 62. In the Middle East, Chinese ceramics quickly became known simply as șinnī, a term that translates more accurately as "chinaware," since it came to designate any Far Eastern ceramic, or indeed any of its Middle Eastern imitations. 


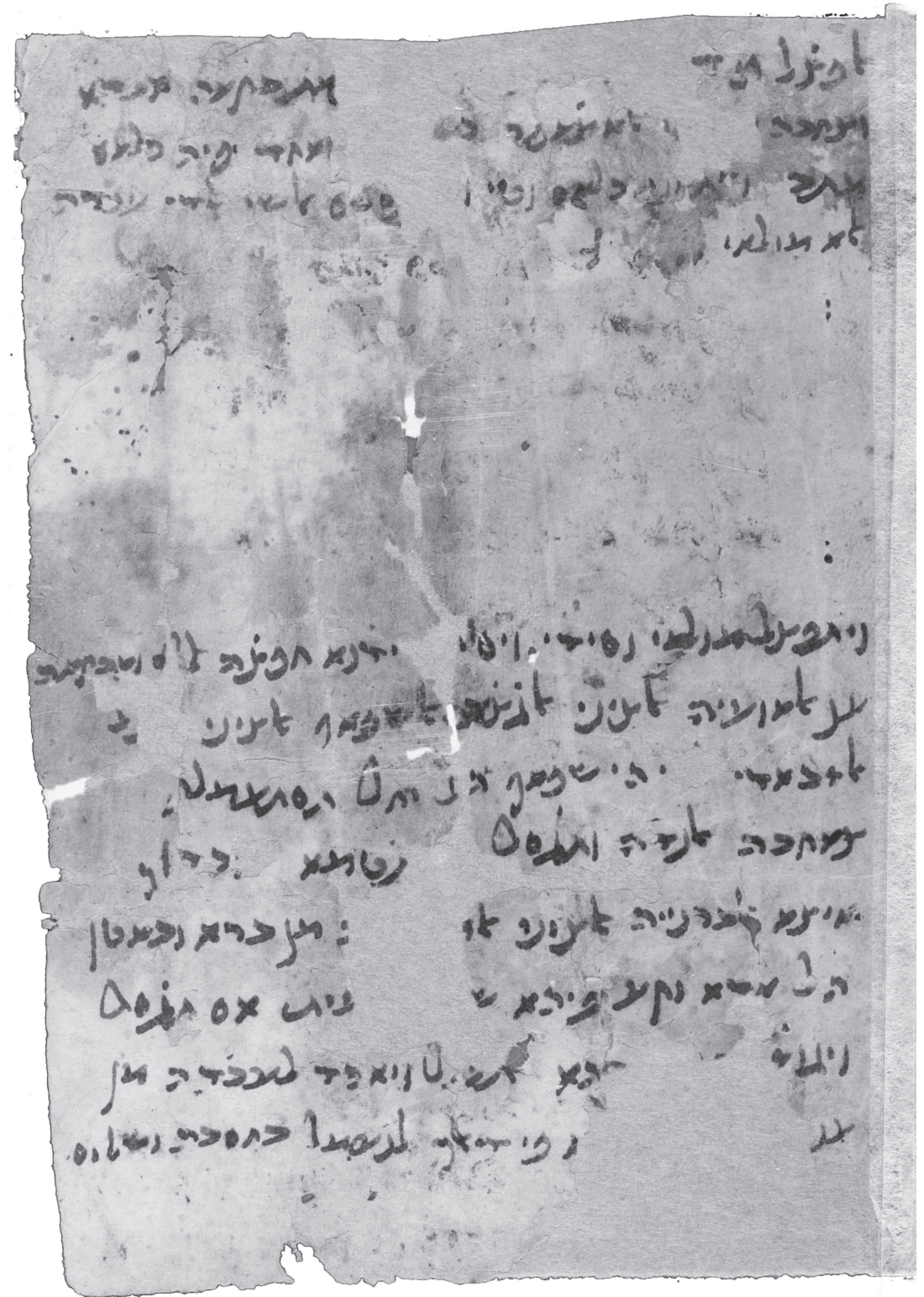

Figure 5. Page from the memorandum written by Madmūn b. Hasan Japheth (Aden, ca. 1135), showing the postscriptum query about șinī vessels. Cambridge University Library, T-S 8J37.1, fol. 2 r.

Reproduced with permission of the Syndics of Cambridge University Library. 
Chinese porcelain became a disruptive substance. Marshalling evidence from contemporary Jewish legal compendia and other writings produced in this milieu, our discussion substantially advances some interpretive angles first suggested by $\mathrm{S}$. D. Goitein and Mordechai A. Friedman. We examine the efforts of Adeni Jews to place this Chinese ceramic fabric among already legislated substances, notably the "neighboring" substances of glass and earthenware, in order to derive clear rules for the proper use and purification of vessels manufactured from it. Indeed, the pattern of encounter and negotiation revealed here is characteristic of rabbinic Judaism's approach to new materials and the technologies behind them, and has a long history running from the popularization of glass vessels in the early first millennium CE through to the modern-day entry of plastics into the kosher home. And yet the specific material culture of Judaism has received comparatively little attention from scholars, so one of the aims of this article is to highlight the unique and rich potential of this field.

Only eight lines long, the query on which we focus amounts to an aside in a much longer memorandum; it might even be described as an afterthought, a postscriptum, since it occupies the last lines of this eighty-eight-line document. Nevertheless, this passage is arguably one of the longest and most complex meditations on the material culture of the region. It yields important new data on the reception of Chinese ceramics in the Middle East, and it adds to a painfully small corpus of texts documenting the early discursive history of this reception, opening new perspectives on their taxonomic integration with the varied material cultures of the region. Even the timing of this query-posed in the 1130s, three centuries after the largescale importation of Chinese ceramics began in the region-contributes new textual evidence for the chronology of exchanges between the Middle East and China. Moreover, this passage is also a significant new source for Jewish legal history. While Tziona Grossmark's innovative work on glass is beginning to sketch out the wider processes through which rabbinic Judaism accommodated new materials, the history of the encounters that produced these new materials is largely unwritten. The questions examined here represent the earliest evidence for the debate within Judaism about the ritual implications of Chinese ceramic fabrics, and thus the beginning of a process of encounter and accommodation. Hitherto, the debate about porcelain has been traced to the much later rulings about Chinese porcelain given by rabbis from the sixteenth century onwards, filtered through the lens of subsequent Jewish jurists the world over. The survival of these questions in a letter, rather than in a legal text, suggests that they should be seen as fresh evidence for the newly contested status of Chinese ceramics in a ritually observant Jewish environment rather than the remnant of a long-standing debate within Jewish law. Addressing the interdisciplinary challenges involved in 
the analysis of this document, this article is co-authored by a specialist in material culture (Lambourn) in collaboration with a specialist in Jewish law (Lieberman).

\section{Decoding Two Questions about ȘinīVessels}

Sometime around 1135, a prominent Jewish merchant in Aden sent a set of very precise questions about șinī ("Chinese") vessels to Mașliah Gaon, the head of the Palestinian yeshiva in Fustat (Old Cairo) who held the post between 1127 and 1139.7 The merchant was Madmūn b. Hasan Japheth, the head of the Jewish community in Aden and also a shipowner and armorer. ${ }^{8}$ The queries were not addressed directly to the Gaon but were to be asked of him, in person, by Abū Sa'īd Ḥalfon ha-Levi b. Nethanel al-Dimyātī, a business partner of Maḍmūn's who was returning to Egypt. Madimun's questions are preserved at the end of a lengthy memorandum (tadhkira) he wrote to Halfon ha-Levi. As is typical of Geniza documents, the memorandum is written in Judaeo-Arabic, contemporary colloquial Arabic written in Hebrew characters. Madimūn writes to Halfon: ${ }^{9}$

Please be so kind, my lord and master, to ask our lord [Mașliah Gaon]may God protect him and keep him alive-about the sinni vessels ('an al-aw'īya al-șinī), the translucent pottery vessels (al-aw'īya al-ghad̄âr al-shaffäf), and all the șinī tablewares [which are] translucent (wa-kull al-zibādī [al-șin] ī hiyya shaffāf): whether it is permissible for a menstruating woman (șāhibat al-nida) to use them and wash them [or] whether they will then be ritually unclean (im titame [Hebrew]). Furthermore, [ask about] a șinī jar (al-barnìya al-șin̄ī) which is [glazed] ${ }^{10}$ outside and inside (al-mu[kallas]a min barra wa bāțin): if something should fall into it (idhā waqa'a fi-hā shayy), [whether] that will render it unfit ([hal ya] $\left.{ }^{\mathrm{c}} \overline{\mathrm{i}} \mathrm{thu}\right)^{11}$ or if it is permissible to wash it and it will be fit for use. Please be

7 Dates of office given in Goitein and Friedman, India Traders, 379. Goitein bases his dating of the memorandum on the fact that Halfon ha-Levi is known to have been in Aden in 1134; however, Friedman adds a more cautious comment, suggesting tentatively that it be dated around 1135 (see 379).

8 For Maḍmūn's biography, see Goitein and Friedman, India Traders, 37-47.

9 English translation from Goitein and Friedman, India Traders, 387, lines 5-12; for the full Judaeo-Arabic transcription and Hebrew translation, see Goitein and Friedman, Maḍūn ha-Nagid, 239, lines 5-12.

10 As Goitein and Friedman indicate in their footnote (India Traders, 387 n. 54) the reading mukallasa or "glazed" is suggested on the basis of the surviving initial letter mem and the final he, and was suggested by Paul Kahle in correspondence with Goitein back in the 1950s.

I I This section of the memorandum is heavily damaged and the restitution of the missing 
so kind as to obtain for me from [our lord an answer] in this matter, so that we may act accordingly."

It is no accident that these very particular queries were sent with Halfon ha-Levi on this particular journey: the memorandum makes it clear that he was transporting a substantial load of presents for family members of Madmūn's in Fustat, as well as for various members of the Palestinian yeshiva there. In particular, he had been charged with delivering a rather generous batch of presents to the Gaon, Mașliah ha-Kohen, alone. Halfon carried six satchels containing over five kilograms of Southeast Asian aromatic woods and spices, one hundred $k^{\prime} b s^{\prime} t$ $\sin i \overline{\text { (an }}$ as yet unidentified Chinese commodity), two South Indian mandīls or kerchiefs, together with a small basket containing "a dast [set] of șīnī bowls (aqdāh), ${ }^{12}$ numbering six bowls." ${ }^{13}$ The dispatch of these presents belongs within a complex and long-drawn out competition between centers of Jewish learning in Iraq and Egypt - the so-called Babylonian and Palestinian academies or yeshivas-for the loyalty of Yemeni Jews, and more practically for their donations. Halfon played a major part in supporting Mașliaḥ's authority in Yemen, and these gifts are evidently connected to this religio-political struggle. Since the authority of an academy was instantiated first and foremost through its role in answering legal queries and resolving community matters, the act of asking these questions can be seen as a further expression of loyalty to the Gaon. ${ }^{14}$ The legal questions and the gift assemblage they accompanied suggest that Mașliah was going to be able to examine the very sort of șinī vessel about which he was being asked to give his opinion. This was not an abstract discussion of legal theory but a real-world question about the application of rabbinic law in lived practice. As Madmūn himself emphasized, he wanted answers so that he could "act accordingly."

text is still open to interpretation. Friedman was not able to make out the interrogative hal transcribed by Goitein but agrees with the interpretation that the verb is most probably ${ }^{c} y t h$ : an uncommon verb with the meaning (Form I) to spoil, ruin (s.th.), which Goitein translated as "render it unfit" (Friedman, personal communication of October 29, 2015). Friedman suggests the literal translation "spoil [it]."

12 The term qadah (pl. aqdāh) is frequently translated "goblet." However, the surviving Chinese vessels are more frequently bowls of various sizes, without stems, the smallest of which might be used for drinking. We therefore prefer the broader translation "bowl," although one might also consider "drinking cup" as an alternative.

13 Goitein and Friedman, India Traders, 383, lines 6-7; for the full list of presents see 382-83, lines 13-17 and 1-7.

14 For a discussion of Madmūn's place in the struggle between the academies of Babylonia and the Land of Israel, see Friedman, Halfon ve-Yehuda ha-Levi, 114-57. 
Maḍmūn's two questions may seem obscure and even strange to those unfamiliar with Jewish practices of purity. But as the following analysis will show, each word was carefully chosen and the pair of questions logically constructed. Before exploring them, it is useful to give a short summary of the principles that structured Jewish ritual practice and generated a unique material taxonomy.

A foundational concern within Judaism centred on issues of purity (tahora) and its corollary, impurity (tuma): the contamination of the pure through exposure to any substance which has itself contracted impurity, and the transmission of that impurity through a variety of modes of contact. Where food and drink are concerned, not only contact with contaminated food and drink but also contact with blood or other bodily fluids can present a problem. The Pentateuch contains commandments for the avoidance of certain sources of contamination when eating, procreating, and worshiping God in the Temple. While a principal source of ritual impurity is contact with a human corpse, several verses in Leviticus introduce other such sources: clean and unclean foods, childbirth, menstruation and other bodily excretions, and skin ailments. Verses in the Book of Numbers also establish the principle that a utensil can be purified by being exposed to the same medium through which it was rendered unclean. Thus, vessels rendered unclean from cooking on a fire would be purified with fire, others rendered unclean through having unclean food boiled in them should themselves be boiled (Numbers 21-23). Early rabbinic sages (tannaim) maintained the importance of the system of purity and even extend its prohibitions to a constituency well beyond the Temple priesthood. By the early third century CE, a considerable volume of oral tradition and legal precedent had developed around this issue, in effect amplifying "the definition of what is affected by uncleanness, how uncleanness is transmitted, and the way in which uncleanness is removed." ${ }^{15}$

In fact, the rabbinic system of purity views liquids as more powerful than solids in communicating impurity and identifies seven liquids specifically: water, dew, oil, wine, milk, blood, and honey. Therefore, vessels or objects that may hold liquids play a particularly prominent role in Jewish considerations of ritual purity, since any utensil capable of containing a liquid may be particularly vulnerable. However, a corollary to the principles governing the transmission of impurity is the binary notion that various materials are more or less resistant to contamination. Once absorbed, impurity may be impossible to remove. Jewish authorities of the Talmudic period (that is, ca. 200-500 CE) centered their discussions of contamination around the porousness of material substances. By the medieval period, Judaism had developed a complex body of knowledge and set of practices relating

15 Encyclopedia Judaica, "Purity and Impurity, Ritual." 
to ritual purity founded on a unique taxonomy that took into account the nature of various material substances as well as their formal qualities.

Each of Madimūn's questions thus sets up a subtly different scenario involving the contamination of a certain sort of șinī vessel, first bowls, and then jars. First, Madimūn asks whether, if a menstruating woman touched these vessels and rendered them unclean, the vessels might be washed to repurify them. The term used here is "wash" (trilitteral root GH-S-L), suggesting a simple act of rinsing the polluted vessels in water, as opposed to the more formal process of immersion in a mikveh, a ritual bath. In either case, water performs a cleansing role, returning the object to purity. However, would the touch of a menstruating woman render these vessels permanently impure? If so, they could no longer be used and might even need to be broken. In his comments on this letter, the great Geniza scholar S. D. Goitein emphasizes the excessively stringent application of Jewish law which this question assumes, noting that it was only in the Land of Israel that "attempts were still made to observe the laws of purity and impurity as in the time of the Temple, when menstruating women forbidden to touch household utensils." 16 "According to normative Jewish law," he further explains, "as formulated in the Babylonian Talmud and later halakhic literature, there is no place for such a question, since no utensil is rendered unclean by a menstruating woman's touch," although menstrual blood itself was polluting. ${ }^{17}$ Goitein notes, however, that similarly stringent practices were observable amongst Jewish communities in both Iraq and Egypt and, on the basis of this query, Yemen too. ${ }^{18}$ Furthermore, as noted by Mordechai A. Friedman, the rank-and-file of the Jewish community might not have been able to determine whether the more restrictive practice was a matter of black-letter law or whether it was simply a pious custom. ${ }^{19}$ In the latter case, given the significant financial loss incurred by breaking a precious șini vessel, it is possible that this stringency might be relaxed. ${ }^{20}$ And yet the query does not engage with the

16 Goitein and Friedman, India Traders, 389. Also discussed in Friedman, "Harhaqat hanida" (Distancing from Menstrual Impurity).

17 Goitein and Friedman, India Traders, 389. See also Friedman, Halfon ve-Yehuda ha-Levi, 156.

18 Goitein, "Stern Religion." Maḍūn's note and additional evidence from the Geniza for these stringencies are discussed in Friedman, "Harhaqat ha-nida," 20; Friedman notes that the more stringent practice of the Land of Israel was known in Yemen.

19 Friedman, "Harhaqat ha-nida," 13.

20 The Austrian authority Jacob Reischer (1661-1733) records that a group of Venetian rabbis had permitted polluted earthenware vessels to be used after remaining unused for only twenty-four hours, but argued that such a leniency should only be allowed in the event of significant monetary loss: Minhat Yacaqov, 85:64; cited in Walter, "Can Porcelain Be Kashered?," 118 n. 21. In present-day debates about the repurification of china or 
question of what should become of an unusable vessel-whether it needed to be broken or, alternatively and far more probably, whether it could be sold outside the Jewish community with no loss of value in the eyes of other consumers. Madmunn's question belongs within a wider discussion among Middle Eastern Jewry of the question of impurity imparted to vessels by menstruant women and recorded in contemporary responsa from Egypt and elsewhere. ${ }^{21}$ However, Madmūn is the only one to frame this question with specific regard to șini vessels, and Aden's dominant position in the trade of the Indian Ocean no doubt played a part in this.

Maḍmūn's second question asks how to repurify a șīnī jar (barnīya) after some "thing" has fallen into it. The halakhic literature is rife with such questions"Rabbi, a drop of milk fell into my chicken soup!" ${ }^{22}$ Where the first question uses the Hebrew term titma, "rendered impure," here the vessel is described as potentially "unfit for use," literally "spoiled" even "ruined." As we have seen, all vessels and their contents can contract impurity through contact with impure substances or people in a state of ritual impurity. But Jewish legal material also places considerable focus on the material from which the vessel is made, whether the external or internal surface of the vessel is concerned, whether the vessel itself is finished or not, the intent of the agents involved, the relative quantities of the various contaminating substances, and whether the act of contamination occurs deliberately. Maḍūn's second question carefully engages these parameters by shifting the discussion from tablewares to kitchenwares, from vessels used for eating or drinking to vessels used for storage or cooking. Where the first question repeatedly mentions the translucency of the vessel type discussed, this question focuses instead on the fact that the vessel is glazed externally and internally (al-mu[kallas]a min barra wa bātin); ${ }^{23}$ and where the first question emphasizes the human source of contamination, the menstruating woman, the agent of contamination here is a generic non-human "thing" (shayy).

Both of Madmūn's questions indicate that contemporary Jews discussed and reflected on the materiality of the objects in their households and did so specifically in terms of the ritual implications of their material properties. In

porcelain dinner services, the issue of financial loss plays an important part in determining a more lenient interpretation. In this vein, contemporary authorities such as Ovadya Yosef (1920-2013, Israel) apply the principle of "significant monetary loss" to permit the use of porcelain dishes on which non-kosher meat has been served (Yabia' Omer, Yoreh De'a I:6, nos. 16, 17, cited in Walter, "Can Porcelain be Kashered?" 118, n. 23).

$2 \mathbf{l}$ See the extensive discussion of these sources in Friedman, "Harhaqat ha-nida."

22 See, for example, Talmud Bavli, Pesahim 75b-76a, concerning permitted matter falling into prohibited, or vice versa.

23 Note that the word al-mu[kallas] $a$ has been restored by Goitein and Friedman. 
this instance, they were particularly interested in the materiality of șini vessels, whether translucent bowls or glazed jars, and were concerned enough to forward a query about this to the religious authorities in Fustat. Was this ceramic fabric so glass-like-in its translucency, perhaps its smoothness and thinness too-that it should in fact be categorized as glass within the rabbinic system? The intense observation and handling of different vessels and utensils implicit in these two questions underlines rabbinic Judaism's unique epistemology, a relationship with the material world forged around complex taxonomies of substances, pollutants, purifiers, forms, and modes of contact. Mary Douglas's now famous anthropological study of systems of ritual purity, Purity and Danger, emphasizes the important role of such taxonomies in controlling pollutants, which were seen as "anomalous" and disruptive to the symbolic system. ${ }^{24}$ But Maḍun's questions helpfully underline that it is not only pollutants that threaten this order but any change to one of its constituent material categories. By the twelfth century many elements of this system-polluting substances, modes of contact-were already clearly and comprehensively identified; however, any new material from which utensils were fashioned represented a challenge. New materials, and the technologies that allowed their manufacture, were also anomalous and disruptive of the system. Grossmark's examination of the processes through which glass vessels entered rabbinic taxonomies is an important milestone in the study of this world view and ultimately the creation of specifically Jewish materialities. Glass's disruption of rabbinic taxonomies is evidenced by the multiple, often contradictory categorizations of this new material-variously likened to metal, earthenware, or even wood, leather, and bone-issued by rabbis well into the twelfth century. ${ }^{25}$ In the present article, it is porcelain's highly vitrified body and glaze that was "anomalous," and which threatened to destabilize established ceramic categories.

\section{What Was Maḍmūn's Șīnī?}

The date of Maḍūn's questions, penned in Aden around 1135, will immediately seem strange to historians of material culture. Chinese ceramics had been imported to the Middle East since the first half of the ninth century, ${ }^{26}$ and Aden

\section{Douglas, Purity and Danger.}

25 Grossmark, "And He Decreed."

26 There is a vast bibliography on the early history of Chinese ceramic imports to the Middle East; for more recent publications including archaeological material, see Rougeulle, "Les importations de céramiques chinoises," and Hallet, "Pearl Cups." While the majority of early Chinese ceramic imports would still have been recognizably ceramic (if novel in their durability, decoration, and form), a smaller number of porcellaneous or porcelain-like wares 
was a key node in the Fatimid Indian Ocean trade, a port that the geographer al-Muqaddasī had described, two centuries earlier, as "the vestibule of China" (dihlīz al-Sīin). ${ }^{27}$ Although medieval Aden has never been formally excavated, a wide variety of Chinese ceramic types have been reported as surface finds at nearby sites ${ }^{28}$ and have been excavated from Fatimid levels at the port of Aqaba on the very northern coast of the Red Sea where they are dated to the second half of the tenth and eleventh centuries. ${ }^{29}$ They have also been found in large quantities at Fatimid Fustat from the later tenth century onwards. ${ }^{30}$ Why then did Madmūn need to ask these questions? Were there not earlier rulings about the ritual status of sinnī vessels to turn to for guidance?

There is suggestive evidence that questions about the ritual status of șini vessels were asked almost as soon as early porcelains began to enter the Middle East in the later tenth and early eleventh centuries. A sixteenth-century discussion by Rabbi David b. Zimra (known as Radbaz) alludes to an earlier ruling which stated that, during Passover, șin̄i vessels were to be treated like earthenware vessels: that is, considered incapable of repurification. The opinion is neither dated nor attributed to a specific authority, however Radbaz acknowledged its great age and that it was recorded in the midst of a collection of responsa which included some from Hai Gaon (939-1038) and other contemporary figures active in the Jewish academies of Abbasid Iraq. ${ }^{31}$ Nevertheless, such discussions appear to

did reach the Middle East at this early period: see Guy, "Rare and Strange Goods," who notes that alongside the 55,000 Changsha bowls in the cargo of the Belitung wreck (an Arabian vessel en route to China from Africa around $830 \mathrm{CE}$ ) were smaller consignments of two or three hundred high-end whitewares and green-splashed whitewares from northern Chinese kilns (20).

27 al-Muqaddasī, Best Divisions for Knowledge, 83.

28 Islamic-period Yemen is poorly surveyed while Aden, as a major port, poses numerous archaeological challenges making it impossible to present well stratified evidence. For the abundance of imported Chinese wares in the twelfth century, see Lane and Serjeant, "Pottery and Glass"; King and Tonghini, Survey of the Islamic Sites; as well as broad introductions to the archaeology of the Aden area by Hardy-Guilbert and Rougeulle, "Archaeological Research" and "Al-Shihr."

29 Whitcomb, "Fatimid Residence at Aqaba," 211. For an overview of ceramic circulation in both the Gulf and Red Sea at this period, see Rougeulle, "Golfe persique et Mer Rouge." Zhao's work on Sharma provides excellent distribution maps for Chinese ceramics all along the Red Sea coast: "La céramique chinoise."

30 For a concise and clear summary of the sometimes confusing publications from the Fustat excavations, with full bibliography, see Bongianino, "And Their Figures."'

3I This early reference was first noted by Goitein and Friedman (India Traders, 387n54), who deemed the source too vague to allow any conclusions to be drawn. Further perusal 
be extremely rare, and we have been unable to identify any other references to șin̄i earlier than Maḍmūn's queries. The paucity of discursive evidence may well reflect the comparative rarity of sini and runs parallel to similar patterns in the halakhic discussion of glass. As Grossmark has shown, a delay of several centuries can be discerned between the first expansion in the production of glasswares in the Middle East, in the first century CE, and the discussion of the ritual status of glass in the fifth century. These are precisely the centuries during which glass became more popularly available in the region and when issues of its use began to affect Jewish households on a regular basis, finally triggering a formal scholarly response. ${ }^{32}$ Against this background, Madmūn's queries might be read as an early sign of the popularization of Chinese ceramics in Jewish households in Aden, and perhaps in the wider Middle East; indeed, this was the conclusion reached by Goitein and Friedman in their edition of the memorandum. ${ }^{33}$ Unfortunately, the absence of archaeological data for medieval Aden makes it impossible to corroborate this hypothesis. However, the substantial contemporary evidence for the importation of Chinese ceramics to Egypt via the Red Sea suggests that Chinese ceramics were in widespread use. One might also point to The Book of Gifts and Rarities (Kitāb al-Hadāyā wa-l-Tuḥaf), a Fatimid compilation by Qadi Ibn al-Zubayr (1053-71), in which șin̄i vessels are rarely mentioned-and then only because of some outstanding feature, such as immense size or unusual color or precious contents, indicating that more common vessels were both ubiquitous and beneath notice. ${ }^{34}$ The overall impression is that while Chinese wares were not everyday objects, they had nonetheless been widely available beyond the Fatimid elite for some time before the $1130 \mathrm{~s} .{ }^{35}$ The timing of this question therefore remains puzzling: why the need to ask about șinī now?

of the commentary shows, however, that Radbaz cites part of the earlier Judaeo-Arabic responsum verbatim, although the text is corrupt in the printed edition. It is clear that the geonic responsum is not answering Madmūn's question but deals specifically with the use of șinī vessels during Passover.

32 Grossmark, “'And He Decreed,"” 191-212.

33 Goitein and Friedman, India Traders, 389.

34 Ibn al-Zubayr, Kitāb al-Hadāyā wa-l-Tuhaf, 384-85 (for example).

35 The contemporary market for, and circulation of, Chinese ceramics beyond the Middle East is the subject of considerable debate. While Whitehouse ("Chinese Porcelain in Medieval Europe") points to the scarcity of finds, and François ("La porcelaine de Chine") argues that their absence from Byzantium and the Christian east is evidence for a fundamentally different taste in ceramics, Milwright (in "Modest Luxuries," 86 n. 16) notes that "stonepaste jars were often the containers for expensive commodities such as spices, medicines, or preserved fruit. It is clear, however, that the vessels themselves were subjects of admiration 
We propose that the timing and particular angles of Madmūn's inquiry can only be explained by the presence in Aden of significant quantities of a substantially new type of Chinese ceramic ware, a fabric that was substantially different from previous imports and one that thus challenged established material taxonomies and elicited new questions from its Jewish consumers. One aspect of this document's significance is therefore its contribution to our understanding of the chronology of Chinese ceramic imports to the Middle East, testifying to the arrival of a type now known as qingbai 青白, “bluish-white," because of the light blue tinge of its glaze: a porcellaneous ware of a new translucency and thinness. ${ }^{36}$ Qingbai was, as Rose Kerr states, "the material from which most later white porcelain bodies developed. It was a white and translucent material that could be thinly potted to create forms of extraordinary delicacy." ${ }^{37}$ Qingbai's exceptional qualities were due to its china stone (petuntse) body, which was almost 50 percent quartz and high in calcia and mica. China stone also contained kaolin "so that it produced a more plastic body" according to Stacey Pierson..$^{38}$ For export to the Middle East, qingbai was frequently decorated with combed or incised floral designs. Finally, the qingbai vessel was glazed with a mixture of china stone mixed with crushed, burnt limestone that produced a hard, vitrified transparent glaze. As Pierson explains, "not surprisingly, tableware was the most important aspect of qingbai production, and much of it was destined for frequent use. The porcelain body is ideal for making durable but light and attractive tablewares." ${ }^{39}$

Porcelain stone was abundantly available in the Jingdezhen area of southeastern China, and it is here, during the later tenth century, that qingbai proper was first developed. ${ }^{40}$ Bing Zhao notes that qingbai begins to appear regularly in Chinese tombs from the year 1000 onwards, and this no doubts marks the beginnings of its wider popularity in China, even if comparatively little is understood about

in medieval European courts."

36 Kessler (Song Blue and White Porcelain, 348-54) has argued that the term actually refers to blue and white underglaze porcelains; however, this interpretation has not been widely accepted.

37 Kerr, Song Dynasty Ceramics, 96. The technology itself was comparatively simple by Chinese standards, involving low firing temperatures (1170-1260 degrees Celsius) with the body made from porcelain stone and glazes that used the same porcelain stone together with a limestone flux. The ceramics were reduction-fired in wood fired kilns.

38 Pierson, Qingbai Ware, 15.

39 Pierson, Qingbai Ware, 18

40 Pierson, Qingbai Ware, 15; and eadem, "Industrial Ceramics," 62-63. See also Zhao, "L'importation de la céramique chinoise," 257 n. 5. 


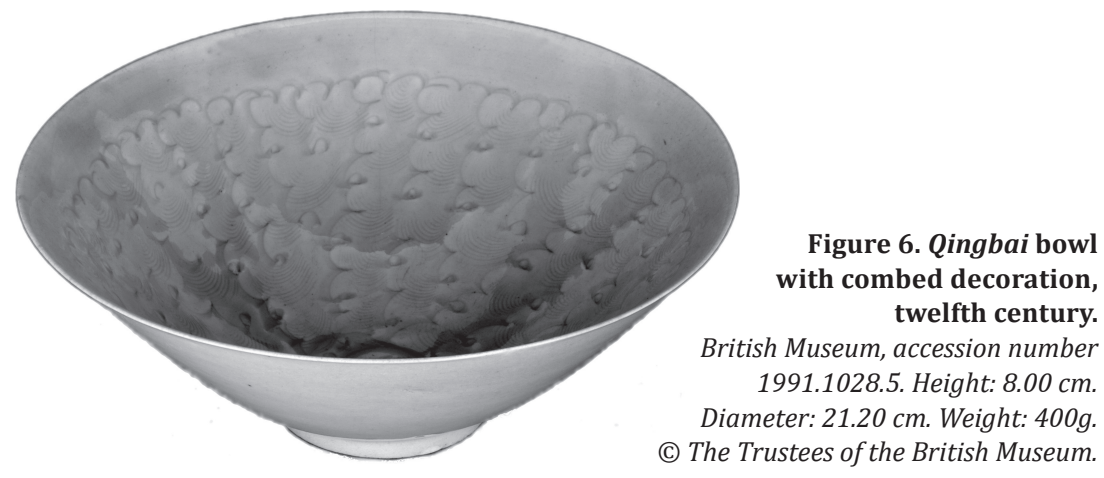

the Chinese consumers of this ware.$^{41}$ From Jingdezhen, the technology of qingbai manufacture spread during the eleventh century to northern and southern China: between the tenth and thirteenth centuries, several dozen qingbai production centers have been identified. ${ }^{42}$ One should note, however, that Chinese ceramic specialists generally reserve the term qingbai for wares produced at Jingdezhen itself or in Jiangxi Province, reserving local names for "qingbai-type" wares manufactured at these other locations, which range over forty-four counties and nine Chinese provinces to the north and south of the Yangzi river. ${ }^{43}$ Qingbai and qingbai-type tablewares were not only extremely popular in China but found a large export market and were exported to more than twenty different countries in Asia, Africa, and Europe. ${ }^{44}$ That wide distribution has been confirmed and refined through subsequent archaeology, on land and at sea. ${ }^{45}$

4I The oldest tomb from which qingbai wares were excavated is dated to $983 \mathrm{CE}$; see Zhao, "L'importation de la céramique chinoise," 263 n. 22.

42 Zhao, "L'importation de la céramique chinoise," 258. We are grateful to the author for clarifying that the French fours refers to production centres rather than to single kilns.

43 Once Yuan period production centers are included, the number rises significantly to over 136 sites producing qingbai wares in the area of Jingdezhen alone for the Song and Yuan dynasties: see Peng, Song Yuan, 30-36. We are grateful to Rosemary E. Scott for this reference.

$44 \mathrm{Li}$, "Chinese Export Porcelain," 103. Of interest for the maritime export trade to the Middle East is the fact that production centers for qingbai-type wares are found in Guangdong and northern Fujian, as well as the area of Minnan, the hinterland of the great maritime port of Quanzhou, in the mid- to late eleventh century: see Pierson, Qingbai Ware, 17. For developments around Quanzhou, see especially Ho, “Ceramic Boom in Minnan," 258-60.

45 The most recent distribution map for qingbai wares in the western Indian Ocean and Middle East is in Zhao, "La céramique chinoise," fig. 222;" see also her "Global Trade," fig. 9. For shipwreck archaeology see, for example, Dupoizat, "Ceramic Cargo." 


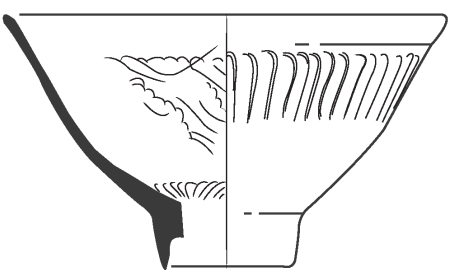

Fine-bodied qingbai bowl, ca. late 11th - mid-12th century, Hutian or Nanfeng kilns (surface find 506/1).

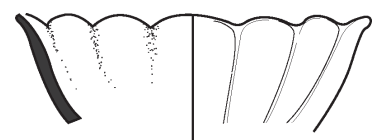

Fine-bodied qingbai bowl with lobed interior and rim, 12th century, Jiangxi Province (surface find S254).

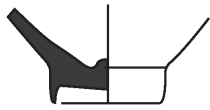

Fine-bodied conical qingbai bowl, 12th century, Hutian or Xicun kilns (surface find S423).

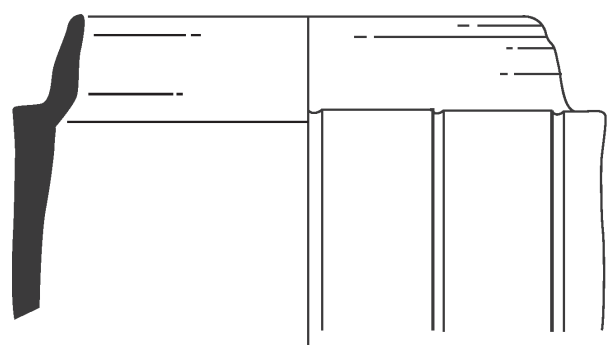

Fine-bodied qingbai box, ca. 1075 - early 12 th century, Hutian or Nan'an kilns (surface find S6).

Medium-bodied qingbai box, ca. 1050-1100, Xicun kilns (surface find S172).

Figure 7. Shard fragments of fine porcelain qingbai bowls and lidded boxes from the entrepôt of Sharma, Yemen, spanning the mid-eleventh to twelfth century. The largest, most complete sherds are often surface finds. Attributions and dates from Zhao, 'La céramique chinoise à Sharma,' Figs. 203-4, 204-1, 206-4, 208-4, 208-5; drawings by Vincent Bernard and Hélène Renel, reproduced by kind permission of Axelle Rougeulle.

Although we cannot prove which ceramic wares Madmūn handled, we wish to suggest that there is a strong likelihood that they were qingbai. The translucency of these pieces would have been in marked contrast to the majority of earlier Chinese imports and would have elicited exactly the puzzled reaction recorded in the memorandum. It is impossible to represent through one example the diversity of qingbai tablewares produced for consumers inside and outside China; nevertheless, by way of general illustration, we include here a photograph of a twelfthcentury qingbai bowl with combed decoration from the collections of the British Museum (Figure 6). To the best of our knowledge, no complete qingbai pieces survive from the Middle East-largely because Islam and Judaism alike prohibited 
burial goods, whereas ceramics from Chinese tombs provide some of the best datable pieces. But Figure 7 shows sherds from a range of qingbai bowls and lidded boxes excavated at the entrepôt of Sharma in the Yemen and spanning the mideleventh to twelfth centuries. The delicate bowls of various shapes and design, usually with a diameter of around five centimeters, may well correspond to the aqdāh - "small bowls" or "drinking cups"—-sent to the Gaon in Fustat for inspection. The lidded boxes found at Sharma, some of which had a diameter of over ten centimetres, may correspond to the barniya jar described in our legal query.

Goitein urged caution when translating the term șin̄i in the Fatimid period, since it was by then applied to wide range of Far Eastern ceramics as well as to their Middle Eastern imitations. ${ }^{46}$ In many contexts, the term is best translated simply as "chinaware," in the inclusive (modern) sense, rather than as "Chinese porcelain" strictly defined. ${ }^{47}$ In this particular instance, however, Maḍuñ was certainly referring to some form of high-fired, porcellaneous Far Eastern ceramic. No contemporary local (Yemeni) ceramics are known to have attempted to imitate Chinese prototypes and thus merit the appellation $\sin _{i}{ }^{48}{ }^{4}$ It would be nonsensical to send comparatively coarse Yemeni glazed wares, even if they existed at this period, to such an eminent figure as Mașliah ha-Kohen; an exchange in the other direction would have been more likely, as Geniza documents indicate that Aden's Jewish elite brought in better quality ceramics from Egypt and Syria. ${ }^{49}$ The batch

\section{Goitein, Mediterranean Society, 4:145-46.}

47 Goitein advocated using the term "fine earthenware," since the low prices indicated for some sinī, and the fact that some pieces were owned by the poorer members of Cairo's Jewish community, would indicate that this was not a high-end ware. In fact, it is more likely that lowerend wares were locally manufactured vessels with a new fritware (also known as stonepaste) body developed in direct response to Chinese porcellaneous bodies. See n. 61, below.

48 Although local Adeni ceramics have not been studied, there is no firm evidence for production of glazed ceramics in the Yemen until the late eleventh and mainly twelfth centuries, and these have been identified at the site of Sharma in the Hadhramaut. In the opinion of the site's excavators, these wares may be predecessors of the much better known Yemeni "mustard ware" so called because of its yellow glaze, which can be dated more securely to ca. 1250 to 1350 and was produced either around Zabid in the Tihama or Aden (Axelle Rougeulle, personal communication of September 17, 2015). For more on this ware, see Rougeulle, "Les céramiques à glaçure," 250-51. So far, the only known contemporary parallels for this ceramic ware are an assemblage of bowls excavated at the port of Ghulayfiqa in the Tihama and dateable to the twelfth century.

49 See, for example, a list of items requested from Fustat for dispatch to Aden, likely on the occasion of a wedding, which included "a basket of good earthenware made in Amid or Fustat": Goitein and Friedman, India Traders, 422, line 17 ("India Book," document II, 44, Westminster Misc. 9). 
of gifts among which this șinī travelled to Egypt-Chinese $k^{\prime} b s^{\prime} t$ (whatever this unidentified commodity was); Southeast Asian cloves, nutmeg, and mace; a variety of aromatic woods; as well as silks from the port of Kollam in southern Malabar-also support the hypothesis of the vessels' Chinese provenance, since it is clear that the entire cache of presents destined for Mașliah ha-Kohen had been assembled through the maritime networks of the eastern Indian Ocean and the South China Sea, with the spices and woods originating in eastern Indonesia, the $k^{\prime} b$ sh't and sīnī in China.

Maḍmūn's questions may accordingly contribute to a still imprecise understanding of the chronology and routes of qingbai imports into the Middle East. Chinese ceramics specialists date the start of large scale exports of qingbai to the late eleventh and early twelfth centuries and some scholars have picked out 1127 as a key date in the development of qingbai as an export product, since it is the date at which the northern Song territories were conquered and the southern Song polity reoriented itself and its exports towards southern China and the south China Sea. ${ }^{50}$ Pierson has suggested, instead, that it was the opening of a maritime administration at Quanzhou forty years earlier, in 1087, which marked the turning point in the development of this ware for export. ${ }^{51}$ For Chuimei Ho, too, there is little doubt that the forty-seven large kilns producing qingbai-type wares that appear ex nihilo in Minnan, the hinterland of Quanzhou, in the later eleventh century, should be dated to around $1087 .{ }^{52} \mathrm{~A}$ rise in exports in the latter half of the eleventh century finds corroboration in contemporary textual sources and the Song dynasty text 萍洲可談 Pingzhou Ketan (Discourse of the Floating Islands) published in 1119, which discusses the maritime trade in Guangzhou during the period 1086-94 and notes that "the greater part of the cargo consists of pottery, the small pieces packed in the larger, till there is not a crevice left." ${ }^{53}$

New archaeological data from the Middle East and East Africa is refining this periodization. Qingbai bowl bases excavated at Fustat have been dated by Bongionino to the Five Dynasties or northern Song, and thus to the late tenth or eleventh centuries. ${ }^{54}$ Qingbai sherds excavated in a Fatimid residence at Ayla on the

50 For example, Kerr, Song Dynasty Ceramics, 103; Teo, “Qingbai Ware for Export," 250.

5I Pierson, Qingbai Ware, 17.

52 Ho, “Ceramic Boom in Minnan," 258.

53 Cited in Miksic, Southeast Asian Ceramics, 73. The text of the Pingzhou Ketan has not been translated into English, and this well-known passage exists in a number of English translations, paraphrases, and summaries of the Chinese original. We are grateful to Rosemary E. Scott for pointing us to this source.

54 Bongionino, "'And their Figures,"” 38 and fig. 11. By contrast, Tadanori Yuba's discussion 
northern Red Sea coast have similarly been dated to the tenth or eleventh centuries. ${ }^{55}$ Such early dates-largely coeval with the earliest finds of qingbai in Chinese dated tombs-indicate that some of the very first qingbai productions, believed by most Chinese ceramic historians to be manufactured at this period primarily for the Chinese market, were reaching consumers in the Middle East with little delay. ${ }^{56}$ This is not as surprising as it may seem: the Middle East's enthrallment with Chinese ceramic technology, growing since the ninth century, may have made it a target market for new ceramic types. ${ }^{57}$ Islamic ceramic historians have certainly accepted the idea of an early contact with qingbai. As Oliver Watson has shown, it is likely these Chinese ceramic fabrics that effected a substantial revolution in Egyptian ceramic technology during the earlier eleventh century. In reaction to such imports, Egyptian potters are believed to have developed a new white ceramic body composed substantially of ground quartz particles that produced a vitrified and sometimes translucent finish: the stonepaste or fritware vessels noted above. ${ }^{58}$ The early and apparently positive reception of qingbai in the Middle East ensured a firm demand in later centuries. ${ }^{59}$ Zhao has even stated that qinof similar, if not identical, shards assigns them a twelfth to thirteenth century date: "Chinese
Ceramics Found at al-Fustat."

55 Whitcomb, "Fatimid Residence at Aqaba," 222. The site is believed to have been abandoned in the early twelfth century, perhaps around 1116, and these ceramics must predate that event.

56 The same is true of East African markets: see discussion and distribution maps in Zhao, "Global Trade," 53, 68, and fig. 9. Qingbai shards are also identifiable at the entrepôt site of Mantai in northern Sri Lanka, believed to have been abandoned in the early eleventh century. The shards are reproduced in the CD accompanying Carswell, Deraniyagala, and Graham, Mantai. We are grateful to Melanie Gibson for pointing out this reference.

57 It should not be forgotten that Chinese ceramics could remain in circulation for lengthy periods precisely because of their perceived value, causing "historic" pieces to be discovered in substantially later archaeological layers. For example, Zhao notes that "at Mahilaka in Madagascar, tenth- and eleventh-century qingbai wares have been discovered from the 'occupation IIa' phase of settlement (which is dated to the thirteenth and fourteenth centuries). This shows that Chinese ceramics might have been kept for centuries as markers of wealth." See "Global Trade," 62.

58 According to Watson ("Chinese-Iranian Relations"), qingbai "could not be adequately copied in earthenwares, which were of necessity thick-bodied and whose opaque glazes did not allow for subtle underglaze decoration. As a solution the Near Eastern potters developed a new fabric based on an ancient Egyptian technology: fritware, compounded of ground quartz with small quantities of clay and glaze. When fired it yielded a pure-white body; if sufficiently thin, it could be translucent. It matched the Chinese ware in all but hardness." See also Watson, "Fritware."

59 Pirazzoli-t’Serstevens, “Une denrée recherchée," 73-74. 
gbai wares "may have been the main category of Chinese ceramics imported into the western Indian Ocean from the late tenth to the mid thirteenth century." ${ }^{10}$ Qingbai may also have been among the Chinese ceramics that, in the twelfth and early thirteenth centuries, inspired Persian potters at the city of Kashan to work with stonepaste and to experiment with substantially new ceramic forms. ${ }^{61}$

Beyond this broad picture, however, details about the phases and routes of qingbai's arrival in the Middle East remain patchily mapped. The general lack of focus on this ware in the Middle East reflects a comparable neglect in Chinese ceramic studies, as Catherine Teo has remarked: "when compared to the longer production periods and popularity of other ceramic types, e.g. blue and white, and celadons, it is not difficult to understand why so little is known of qingbai wares." ${ }^{62}$ One important site that offers data for a better understanding of qingbai imports to the Middle East is the entrepôt of Sharma on the northern Hadrami coast, excavated between 2000 and 2001. The commercial nature of the site has yielded a fine-grained phasing of Chinese ceramic imports over the lifetime of the entrepôt between ca. 980 and ca. 1150. Analysis of the these ceramics by Zhao has demonstrated that the qingbai wares from Jingdezhen, along with qingbaitype wares from other kiln sites in China, together represent 41.5 percent of the Chinese ceramic imports found throughout the lifetime of the site, with a peak in importation between 1050 and $1120 \mathrm{CE} .{ }^{63}$ During this period, at least twenty-four different groups of ceramics were imported from at least eleven different ceramic production centres, principally in Jiangxi and Guangdong provinces; of these, the greatest variety of types, fifteen or 62.5 percent, was seen in qingbai wares from

60 Zhao, “Global Trade," 74.

6 I Research is currently underway in this area, led by Melanie Gibson and presented by her at two recent conferences: "The Impact of Song Period 'Chīnī' in Iran" (panel, "Things and Their Ideas: Exchanges in the Visual and Material Cultures of Islamicate Asia," convened by Sussan Babaie and Elizabeth Lambourn at the Association of Art Historians 41st Annual Conference and Bookfair, University of East Anglia, April 11, 2015) and "The Impact of Southern Song Chīnī in the Production of Twelfth-Century Kashan" (British Museum Study Day, “Chinese Qingbai Ceramics and their Contexts," May 15, 2015).

62 Teo, “Qingbai Ware for Export,” 250.

63 The site chronology for Sharma changes subtly between Zhao's first publication of the qingbai shards in 2004 as "L'importation de la céramique chinoise," and the final chapter in the site publication published in 2015 as "La céramique chinoise." In 2004, Phase III was dated to ca. 1050-1120 and Phase IV to ca. 1120-50; in the final publication, Phase III terminates around 1060, Phase IV spans ca. 1060-1120, while Phase V now marks the period 1120-1220. 
Jingdezhen and in qingbai-type wares from other Chinese kilns. ${ }^{64}$ In sum, the data from Sharma demonstrate the existence of intense commercial networks connecting the Arabian coast to kilns across China and exhibiting a high preference for the importation of qingbai tablewares from Jingdezhen or qingbai-type wares from other manufacturing centres, particularly between 1050 and 1120 but continuing well into the mid-twelfth century.

Sharma is, of course, only one entrepôt site, and it was also a redistribution centre; we do not know where its Chinese imports moved on to, or by whom they were moved. Axelle Rougeulle, Sharma's principal excavator, has suggested that Aden might have been one of these destinations and this part of the coast was certainly an important crossroads for ships crossing the western Indian Ocean, either north to the Gulf or south to the Red Sea. Whether or not Sharma supplied Aden in qingbai wares and other Chinese ceramics at this period, the site offers a template that might be applied to other sites in the Arabian Peninsula. It further suggests that Madimūn's que stions were posed after almost eighty-five years of substantial qingbai imports to the region, time enough for merchant elites to accumulate a substantial number of such vessels in their homes, and to begin questioning the material properties of these items. Madmūn's question implies that his own household contained large quantities of translucent Chinese wares: he asks "about the șinī vessels ('an al-aw'iya al-șinī), the translucent pottery vessels (al-ghadāar al-shaffā $)$, and all the șinī tablewares [which are] translucent ([wa]-kull al-zibād, [al-șin] ī hiyya shaffāf)." The accumulation of large quantities of fine qingbai wares in Aden suggested by this document may thus represent some of the earliest textual evidence for their large scale commercial trade in the western Indian Ocean, corroborating the archaeological evidence from Sharma and evidence emerging from other sites in the western Indian Ocean.

The site of Sharma also preserves exported Chinese ceramics previously believed to be unique to the Southeast Asian market. Research on qingbai imports in Southeast Asia has noted that Chinese qingbai kilns manufactured a type of small lidded box specifically for Philippine and Indonesian consumers; the form is never found in China itself. ${ }^{65}$ Their size suggests that they were used to hold preserved fruits, sauces, spices, and, above all, medicines and ointments. Yet in her analysis of the qingbai found at Sharma, Zhao identified exactly this box type: ${ }^{66}$ perhaps a clue that the qingbai wares reaching Sharma were not purchased

64 Zhao, “L'importation de la céramique chinoise," 263-64.

65 Teo, "Qingbai Ware for Export," 249. These small boxes came in various forms notably globular or square with two to three lugs on their shoulders.

66 Zhao, "L'importation de la céramique chinoise," 275, figs. 3-12 and 3-13. 
directly from China but had made their way from Indonesia or the Philippines. Such boxes in particular might have reached the Yemen, not as commodities in their own right, but as containers for other exotic products from those regions. ${ }^{67}$

The evidence from Sharma encourages us to look at commercial networks of ceramic supply, but we should not dismiss the possibility that some Chinese wares were obtained via noncommercial modes of exchange. New research on provisioning and supply in the Indian Ocean is demonstrating the importance of private transportation networks among Jewish India traders, particularly for household items, and it is possible that some of the Chinese ceramics in Madmūn's household reached him through such networks. ${ }^{68}$ As far as we know, Jewish merchants from the Middle East were not established in Chinese ports, and much skepticism has been cast on Benjamin of Tudela's twelfth-century description of China; ${ }^{69}$ nevertheless, Geniza documents do record that Jewish merchants at this period traded in Southeast Asia, where qingbai vessels were actively imported..$^{70}$ Nor should we disregard the other, non-Jewish networks that Madmūn's close association with Bilāl b. Jarīr, the governor of Aden, likely opened for him, and which may well have extended directly to China. The contemporary historian 'Umāra al-Hakamī noted that, when Bilāl b. Jarīr died in 1151 or 1152, his chattels included "Indian rarities and Chinese fineries (tuhaf al-Hind wa altăf al-Sīn)." ${ }^{\prime 1}$ There is ample evidence from Chinese sources that many other Middle Eastern communities were permanently represented in Chinese ports at this period and maintained exchanges with the Middle East. ${ }^{72}$ There were also regular exchanges of embassies between the Middle East and China. Indeed, the sixty-five years between 1071 and 1136 saw some thirteen merchant-led tribute missions from Arab lands (the Ta-Shi) to the Song court. While Chinese sources do not distinguish between Fatimid-sponsored embassies, which traveled the Red Sea route, and those from the Sunni Abbasid Caliphs in Baghdad, which very likely travelled via the Gulf, certain gift assemblages point clearly to embassies travelling via the Red Sea route and thus likely to

67 The Philippine and Indonesian export markets for qingbai are especially well researched: see Teo, "Qingbai Ware for Export."

68 See Elizabeth Lambourn's forthcoming monograph Abraham's Luggage: A Social Life of Things in the Medieval Indian Ocean World.

69 See Encyclopedia Judaica, "Benjamin (ben Jonah) of Tudela."

70 See letters from merchants departing for Southeast Asia in Goitein, Letters of Medieval Jewish Traders, letters 46 and 47, 227-29.

7I From the Ta'rīkh of 'Umāra al-Hakamī (d. 1174) cited by Kay, Yaman, 80 (and, for the Arabic, 59). Al-Hakamī was a Yemeni and a contemporary of Bilāl's.

72 For a good overview of sources, see Chaffee, "Diasporic Identities”; and Heng, "Shipping." 
have come from the Fatimids or their local allies in the Yemen. ${ }^{73}$ Envoys were often merchants, and they were always recompensed for their tribute, and not infrequently with ceramics; it is not impossible, then, that returning merchant envoys brought qingbai back with them. Whatever their route to Aden, the six șini cups dispatched to Fustat in the satchel of gifts afforded the perfect opportunity for Madmūn to clarify the status of qingbai within Jewish material taxonomies.

\section{Taming a Disruptive Substance}

Maḍūn's eight-line query represents the earliest securely dated and localized evidence for a debate about the material status of porcellaneous Chinese ceramic fabrics within Judaism. The translucency and vitrified body of these wares disrupted established material taxonomies, confounding expectations of how a ceramic fabric should "look," "feel" and "behave"; it was a disruptive substance. Since earlier șini fabrics scarcely appear to have been the object of rabbinic legislation, Madimūn had no existing rulings to turn to, and, in the absence of these, he began to formulate his own ideas based on empirical observation of the vessels and by analogical reasoning from known materials. As Goitein briefly indicates in his commentary on the document, Madmūn's two questions are carefully crafted to frame sinin vessels between the much better known materials of glass and earthenware. ${ }^{74}$ As we have seen, the new material (and technologies) of glass had already been incorporated into rabbinic Judaism during the first half of the first millennium CE. Madmūn and the Gaon would have been able to turn to an abundant body of legislation about earthenware, glazed earthenware, and glass which were all well legislated by the twelfth century-even if contradictory opinions persisted. In this section of our article we unpack the reasoning and precedents both men might have applied to this problem.

Maḍmūn's first question, about a menstruating woman's contact with șinni tablewares, is notable for its repeated emphasis on the translucency of the vessels under discussion. As we have seen, Madmūn refers to "the translucent pottery vessels" and "all the șin̄i tablewares [which are] translucent." Goitein remarks that this chosen vocabulary points to an understanding of șinī as a glass-like substance. Translucency is indeed a quality more often associated with glass than with

73 See Bielenstein, Diplomacy and Trade. For example, in 1131 an Arab embassy fronted by a certain P'u-ya-li (likely Abu 'Ali) brought thirty-five large rhinoceros horns and 209 large elephant tusks, products of East Africa; another in 1136 offered frankincense, a product of the Arabian coast north of Aden, valued by the Maritime Trade Bureau at Quan-zhou at 300,000 strings of 1,000 cash: a huge sum (362).

74 Goitein and Friedman, India Traders, 378. 
ceramics, which are generally opaque, and the use of the term shaffäfin Maḍūn's question points clearly towards this other material. The translucency and glasslike properties of certain Chinese ceramic bodies had already been noted by Middle Eastern merchants as early as the ninth century; the author of the Akhbār al-Sin wa-l-Hind, a mid-ninth century Arabic language manual on trade with India and China, reports that the Chinese "have excellent quality pottery (ghadāar) from which are made bowls (aqdāh $)^{75}$ as fine as [glass] flasks (al-qarāwīr): one can see the gleam of the water through them, even though they are made of pottery." ${ }^{76}$ This material similarity continued to be recorded by later Middle Eastern authors. The Iranian polymath al-Bīrūnī (d. 1048) is perhaps most explicit in his comparison of Chinese ceramic fabrics with glass. In The Sum of Knowledge about Precious Stones (Kitāb al-Jamāhir fī Ma'rifat al-Jawāhir) al-Bīrūnī includes bowls made from șinīyya (al-qișa' al-șinīyya), that is from "China stone," a separate category of "precious stone," and places them directly after his discussions of glass (zajjāj) and glass enamel (minā'). Al-Bīrūnī was most concerned with documenting how șiniyya was used in the manufacture of Chinese ceramics, and as part of this he reported (erroneously) that the best bowls were like glass, for "if they break, they are molten and recast." According to one of al-Bīrūnī's informants, the best bowls were "thin of body, sheer" (al-raqīqa al-jirm al-șāfiya). ${ }^{77}$ Al-Tha'ālibī (d. 1038), writing in Iran around the same period, also included Chinese porcelain among the specialities of the country in his Book of Curious and Entertaining Information (Kitāb Lațā'if al-Ma'ārif). He describes how the Chinese "have fine, translucent pottery (al-ghadā'ir al-mustashaffa) which they cook food in and one piece of this may be [used as] a pot on one occasion, a frying pan another or a serving dish another": that is, it could be used for boiling, frying, and serving. ${ }^{78}$ Mustashaffa derives from the same Arabic trilitteral root (SH-F-F) as the term shaffäflater used by Maḍūn, signifying transparent, diaphanous, or translucent. On occasion, Chinese writers also pondered the material similarities between glass and ceramic

75 For the translation of the term qadah (pl. aqdāh), see discussion in note 12, above.

76 'Wa la-hum al-ghaḍār al-jayyid wa yacmal minhu aqdāh fĩ riqqa al-qawārir yarā ḍau' almā' fỉhi wa huwwa min ghaḍā": Akhbār al-Sīn wa-l-Hind, 16. Although the author does not explicitly compare these ceramics to glass, the fabric's glass-like qualities are implied and were highlighted by the translator Jean Sauvaget in his French translation of this text.

77 Al-Bīrūnī, Kitāb al-Jamāhir fì Ma'rifat al-Jawāhir, 195.

78 "Ẃa la-hum al-ghaḍāin al-mustashaffa yuṭbakh fī-hā al-țabīkh fa-yakūn al-wāḥid minhā qidr marra wa miqla tāra wa qaș'a ukhrā”: al-Tha'ālibī, Kitāb Lațā'if al-Ma'ārif (ed. Abyari and Sayrafi), 221. Bosworth's translation (Book of Curious and Entertaining Information, 141) explicitly associates the qidr with boiling and the miqla with frying. A different translation again is given in Kahle, "Chinese Porcelain,” 338. 
fabrics. Although in China itself the highest quality ceramics aspired to be jade or silver-like, at least one Tang writer, Wei Zheng (580-643), noted that "greenware [celadon] was no different from glassware."79 Madmūn would obviously not have been aware of Chinese material taxonomies, and there is no suggestion that he even knew these two Islamic sources; nevertheless, we suggest that all three passages perfectly illustrate the complex technological position of porcellaneous ceramics whose ingredients do indeed produce a vitrification of the body and glaze, rendering them glass-like. It is therefore with glass, porcelain's most recent material ancestor, that we begin our discussion.

Glass was not one of the materials originally legislated in the Pentateuch, as noted above. However, as it became more common in the Middle East over the course of the first two millennia BCE, it was finally declared subject to ritual impurity by the mid-second century BCE. Thereafter, glass was considered a substance capable of contracting impurity and entered Jewish legal debate. The central and more complex problem that ensued, as later with șin̄in, was whether, and if so how, glass vessels could be returned to a state of purity. To determine that, as Grossmark's work has shown, the new substance needed to be framed by existing material categories. The distinction between the new glass vessels and the much older tradition of earthenware utensils is outlined in the Babylonian Talmud, ${ }^{80}$ a central text of rabbinic Judaism composed in Mesopotamia between ca. 200 and 550 CE. The timing of this integration coincides with the popularization of glass vessels across the Middle East as a result of the invention of glass-blowing in Syro-Palestine in the first century CE.

Yet opinions were contradictory, and glass refused to be tamed. The most comprehensive discussion of the ritual purity laws relating to glass vessels is found in Tractate Kelim of the Mishna (itself generally held to have been redacted around $220 \mathrm{CE}$ ). There, glass vessels are grouped with wood, leather, and bone utensils: "in order to purify the contaminated item, its existence as a vessel must cease, which is usually done by breaking it." ${ }^{81}$ Broken glass can be melted and remade relatively easily, but the vessel is nevertheless destroyed. However, rabbinic Judaism gave ample space for alternative analysis and categorizations, and the Talmudic sage Rav Ashi (fl. 375-427 CE) argued that "utensils of glass, since they may be repaired when broken, are like utensils of metal."82 By "repaired," Rav Ashi clearly refers to the fact that, like scrap metal, broken glass (i.e., glass cullet) may be

79 Cited in Hsueh-Man, "Luxury or Necessity," 73 n. 7.

80 Talmud Bavli, 'Avoda Zara 75b.

8I Grossmark, “'And He Decreed,'” 203.

82 See Talmud Bavli, 'Avoda Zara 75b. 
melted and reworked; accordingly, glass utensils could be treated like metal ones. And yet glass was arguably not tamed for another seven hundred years when Moses Maimonides's highly influential Mishneh Torah, an encyclopedic systematization and restatement of Jewish law written at the end of the twelfth century, grouped glass vessels with earthenware based on the fact that glass was made from earth, specifically sand. Based on this reasoning, Maimonides declared glass to be incapable of repurification in a mikveh, a ritual bath. ${ }^{83}$

We do not know which opinion about the status of glass was current in Egypt and the Yemen in the 1130s; Maimonides's influential ruling postdates Maḍūn's question by half a century, and more liberal interpretations of glass's potential for repurification continued to circulate. The early medieval Avot of Rabbi Nathan, a discourse centered around the mishnaic tractate Avot (which was likely composed in Mesopotamia in the wake of the redaction of the Babylonian Talmud, between the sixth and ninth centuries) approached the issue through the question of porousness rather than repair. It rules that a glass vessel is not considered absorptive or porous like earthenware and could thus be used for both dairy and meat, and restored to a state of purity simply by washing: "three things are said of a glass vessel. It does not absorb, it does not discharge, and it shows everything that is inside it. In a hot place it is hot; in a cool place it is cool." ${ }^{84}$ The material proof of glass's neutral absorptive qualities was that it did not preserve heat or cold; furthermore, being transparent, it was possible to see that no substances had been absorbed into the fabric. The Avot of Rabbi Nathan became a widely influential text and its ruling on glass vessels can be found repeated in the late twelfth/early thirteenth century by the German Rabbi Eliezer b. Joel ha-Levi ("Raviya"). Discussing the same issue-namely, the separation of meat from dairy in Jewish cooking - the latter added the proviso that Jews could even use glass vessels purchased from a gentile which might have served in ritually impure or idolatrous contexts.

Old glass vessels [belonging to a gentile] ${ }^{85}$ that have been used for leaven [or by a gentile] or for wine libations are permissible, since they do not absorb. So it is said in a Baraita of Avot de-R. Nathan: three things are said about an earthenware vessel and three about a glass vessel. An earthenware vessel absorbs, discharges, and preserves what is inside it, which is

83 Maimonides, Mishneh Torah, Laws of Utensils (Hilkhot Kelim) 1:5. For an introduction to the Mishneh Torah, see Twersky's Introduction to the Code of Maimonides.

84 Avot de-Rabbi Natan, (a), ch. 42. We are grateful to Zvi Stampfer for suggesting this reference.

85 These words are bracketed in the Hebrew text, indicating the editor's suggestion that they be deleted. 
not true of a glass vessel. The reason is that it is smooth, as we say about the heart: (Talmud Bavli, Pesahim 74b), "The heart is different because it is smooth," and it does not absorb (for if so it would be like the old ones) ${ }^{86}$ and does not discharge. ${ }^{87}$

If the more liberal rulings of Rav Ashi and the Avot of Rabbi Nathan were applied, Maḍmūn's alignment of this new șinī fabric with glass, implied by his emphasis on its translucence, would open the way to a variety of non-destructive methods of repurification. Whether by analogy with metals or contrast with porous earthenware, șinī could be repurified by washing in cold water, boiling, or heating directly in a fire.

Siñi's high heat resistance would have been especially valuable in this context, since repurification also took into account the temperature of the polluting substance, often non-kosher food, with which vessels had come into contact. The operative principle, canonized in the Talmud, ${ }^{88}$ is "as it absorbs, so it expels" (kebol'o, kakh polto): that is, a vessel which was used for cold food may be repurified and made usable through washing in water, while a vessel used for boiling or directly cooking non-kosher food on the fire required more robust processes (immersion in boiling water or immersion in fire until the vessel itself becomes burning hot, respectively). Although the thermal resistance of Chinese ceramics is mainly mentioned in Islamic sources and in relation to their use for cooking-as al-Tha'ālibī noted, translucent Chinese pottery could be used in cooking as a pot, a pan, and a serving dish-it is clear that in the Jewish context these same properties made Chinese ceramic fabrics extremely versatile in terms of the variety of repurification methods that vessels could sustain without cracking.

Maḍūn's second question shifts to considering șinī storage vessels and the pollution of the interior of such vessels by non-human agents. These șinī vessels are not specifically described as translucent because this quality was irrelevant to the particular angle of reasoning this question explored. Instead, Madmūn focuses on the fact that both the exteriors and interiors of these vessels are glazed. In framing this question, he appears to be testing șinī against earthenware and glazed earthenware vessels, perhaps the most obvious categories of comparison

86 Note that the modern editor of this classical text, Avigdor Aptowitzer, read the parenthetical phrase as incomprehensible in their present location and placed them after the word "and does not discharge"; cf. Sefer Raviya, 91 n. 23.

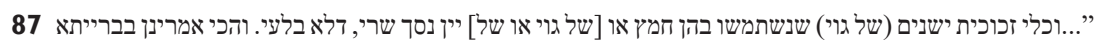

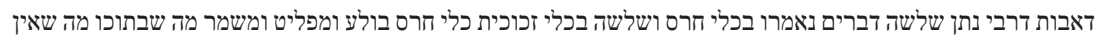

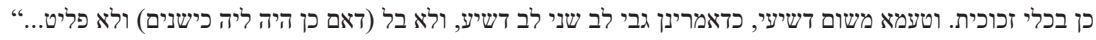
Sefer Raviya, Part 2, Section 464, 91. We are grateful to Zvi Stampfer for suggesting this reference.

88 Talmud Bavli, Pesahim 30b. 
for Chinese ceramics and ones for which an abundant halakhic literature already existed. Guidance on the treatment of earthenware vessels is given in the Pentateuch and provides the basis for subsequent rulings on this material. As Leviticus 11:33 instructs, "any earthenware container into whose inner space one of these [dead creatures] will fall, whatever is inside it shall become unclean, and you shall break [the container] itself." ${ }^{\prime 9}$ From Leviticus onwards, earthenware vessels were understood to behave in a distinctive manner, contracting impurity only via their inner spaces, and to be particularly intransigent in terms of repurification. Because earthenware is understood to be less durable than glass or metal, it may not be purified through immersion in boiling water or in fire, and therefore if it has come into contact with non-kosher food that is hot it may not be purified at all. ${ }^{90}$

This passage from Leviticus clearly provides the starting point for Madmūn's query about the ritual status of a șin̄i jar should some polluting "thing"—a maggot or polluting substance-fall into it, the caveat being that this jar is glazed inside and out; it is not unglazed earthenware. Does glaze substantially alter the properties of the interior of a ceramic jar and thus the processes through which it can be rendered pure again? This specific question points to a smaller body of opinions which developed as glazed ceramics became more common in the Middle East during the first half of the first millennium CE. While one authority, Ravina (d. 499), likened glazed earthenware to glass, which (like metal) might be repurified by washing or immersion in boiling water or fire, his near contemporary Rav Ahai (late fifth/early sixth century) viewed glazed ceramics as behaving like unglazed earthenware; as instructed in Leviticus, therefore, glazed ceramics could only be rendered pure again by being broken and effectively rendered useless in the process. These opposing conclusions depended on whether glazed vessels were judged according to their original or their final states: the clay body of a glazed vessel arguably made it taxonomically close to earthenware; however, its final glaze, which in the Middle East incorporated lead, brought it close to metals and by association to glass. ${ }^{91}$ According to the Babylonian Talmud, it was the latter opinion that prevailed and established that glazed ceramics should be judged

89 Cf. Maimonides, Mishneh Torah, Chapter 13, Halacha 1.

90 For further detail, see the sources in Newman, ha-Ma'asim li-vene Ereș Yisrael, 52 and following; Margulies, Hilkhot Ereș Yisrael, 93; and Friedman, “Shne qeț'aim mi-sefer,” 14-36.

91 “Concerning glazed utensils Rav Ahai and Ravina differ; one maintains [that it must be treated] according to its original state, while the other maintains [that it must be treated] according to its final state. The ultimate decision is [that it must be treated] according to its final state," “........”. Talmud Bavli, 'Avoda Zara 75b. Note that Marcus Jastrow (Dictionary of the Targumim, 1335) translates this word as indicating a powdered lime glaze. 
according to their final state. The glazing of the entire vessel appears to have been particularly important in allowing this conclusion: in a fourteenth-century Catalan commentary on Isaac Alfasi's eleventh-century Talmudic digest, the jurist Rabbenu Nissim of Gerona explained that the lenient treatment of earthenware items covered in a glaze applies only when these items are glazed both on their exterior and interior surfaces. ${ }^{92}$

While Talmudic literature had considered glass, earthenware, and items glazed on both sides in a manner that made their absorptive properties (or, perhaps more correctly, their lack of absorption) like glass, the Talmud had not been able to consider porcellanous, vitrified ceramic bodies. The second question therefore frames this hypothetical barniya between earthenware and glazed vessels. We cannot be certain that the opinion of Ravina and his successors was also followed in twelfth-century Egypt and Yemen. However, Madmūn's emphasis on the finished state of the vessel, on the fact that his șini jar was glazed both inside and out, appears designed to point towards this ruling, distancing his glazed șini jar from earthenware and allowing it to be repurified according to the far more flexible methods prescribed for metals and glass, and sparing him the financial loss of destroying it or having to sell it.

\section{Conclusions}

We do not know what reply Maḍūn received from the Gaon; few of the letters sent from Egypt to the Yemen ever made their way back into the Cairo Geniza. Nor is it possible to judge the contemporary currency of such questions and the answers tendered, since only one trace of this debate has been identified: Madmūn's memorandum. And yet porcelain clearly remained a disruptive substance within Jewish material taxonomies. As Chinese ceramic imports grew in volume from the later sixteenth century, and as Europe developed its own approximations of chinaware, questions about șinnìs material status became more common and leave more significant textual traces. Although there is currently no comprehensive compilation and focused study of later debates about its purification, one might point to the record of the experiments carried out in the sixteenth century by the Egyptian and Palestinian authority Radbaz, who tested șintr's porosity. In one experiment, a piece of china was weighed before and after having been soaked in food, and was found to have taken on additional weight after having been soaked. ${ }^{93}$ In the sec-

92 Rabbenu Nissim on Alfasi, 'Avoda Zara 39b-40a, s.v. "ve-hilkheta ke-sofo".

93 Shut ha-Radbaz, 3:401; discussed but incorrectly cited in Walter's "Can Porcelain be Kashered?" 
ond experiment, a dish was heated and Radbaz noticed "a flame emerge from the dish, [so] he concluded that there must have been residue in the china which was the source of the combustion." ${ }^{94}$ From the two experiments, Radbaz concluded that china was porous like earthenware and therefore impossible to render clean again. Nevertheless, his opinion did not settle the question and Chinese porcelain continued-and continues-to disrupt rabbinic taxonomies.

Even with the advent of modern materials science in the nineteenth and twentieth centuries, which finally provided incontrovertible evidence for the vitreous nature of porcelain, porcelain continues to be evaluated in Judaism within material taxonomies established in late antiquity; in that context, porcelain can only ever be problematical and "Other." The modern prevalence of porcelain or bone china dinner services and the proliferation of porcelain for sinks and other kitchen fittings has engendered a veritable flood of queries about the status of these materials, traceable through the numerous questions and answers exchanged online between observant householders and rabbis. ${ }^{95}$ There is, however, some suggestion that rabbinic authorities in North America and Europe are increasingly reaching the consensus that porcelain is not "kosherable." The subtle premodern calibrations of porcelain between earthenware, glazed ceramics, and glass examined in this article are increasingly giving way to its inclusion among a bulk group of ceramic technologies to which one rule applies: as Wayne Allen wrote in 1994, "the standard halakhic rule is that earthenware, enamel, porcelain, and glazed china cannot be 'koshered." 96 Instead, it is the principle of "great loss" (hefsed merubeh ${ }^{97}$ on which a leniency might be hinged, should an heirloom dinner service (for example) have been exposed to non-kosher food items. ${ }^{98}$ Madimūn's queries show that these modern questions must be understood in a deeper historical context: the disruptive potential of ceramic materials within Jewish material taxonomies has been debated for well over two millennia. Indeed, the introduction of new technologies for the production and storage of food continue to challenge the existing typologies established within Jewish law. The mass production

94 Cited in Walter, "Can Porcelain be Kashered?" 113 n. 9. In the words of Ibn Abi Zimra, "....." (This was my experiment: I took a piece [of porcelain] and put it in the fire, and a flame came out of it just like those utensils which absorb [...]).

95 See, for example, "China Dishes, Porcelain" < http://www.aish.com/atr/China-DishesPorcelain.html> [accessed April 8, 2015].

96 Allen, “Kashering China," 147.

97 Jewish law overrides certain prohibitions ascribed to rabbinic (as opposed to Torahitic) law in the case of a significant financial loss; cf. Encyclopedia Talmudit, "hefsed merubeh."

98 Allen, "Kashering China," 149-50. 
of plastic from the 1940s onward has challenged rabbinic authorities to consider whether plastic should be considered akin to stone (considering its petrochemical source) and therefore not subject to the absorption of impure foods, or like wood and therefore porous. ${ }^{99}$ The contemporary responsa call to mind the question Maḍūn posed to Mașliah Gaon in the twelfth century.

Maḍūn's queries open unique new perspectives on the reception of Chinese ceramics in the wider Middle East. They add nuance to a story that has tended to focus on technological and formal responses and to treat the region's inhabitants as a monolithic, apparently areligious, group. They remind us that a significant religious minority within the largely Muslim population might have a radically different history of reception compared to other faith communities. Muslim, Christian, even Zoroastrian ritual purity systems operated within very different material taxonomies, and there is no evidence that any of these faiths ever questioned the place and propriety of Chinese ceramics. Instead, for most Middle Eastern consumers, the glass-like qualities of certain Chinese ceramic vessels would have been a matter of wonder rather than concern. Al-Tha'ālibī's short description of Chinese ceramics occurs in a chapter on the special crafts practiced by different peoples, presented alongside Chinese statues, paintings, patterned silks, felts, and other manufactured things as evidence for "the skill of their hands and for their expertise in fashioning rare and beautiful objects." ${ }^{100}$

Maḍūn's questions also represent an important addition to the small corpus of textual references to șinī in sources from the medieval Middle East. As work on the much later European reception of Chinese ceramics has demonstrated, what people thought and wrote about chinaware, and how they did so, offers an essential complementary perspective to surviving material evidence. ${ }^{101}$ Physical and visual analysis grounded in material culture studies, now supplemented by an array of advanced scientific techniques, have provided insights into the most microscopic details of design and manufacture, information unlikely to have entered contemporary written records. On a macro scale, as analysis of the Chinese ceramics from the site of Sharma has shown, shard percentages can give us a good idea of the proportion of Chinese ceramics within the larger ceramic

99 See, for example, Responsa Minhat Yișhaq (Isaac Jacob Weiss, twentieth-century Poland, Palestine and Israel), 8:92; Responsa Șiș Elicezer (Eliezer Yehuda Waldenberg, twentieth-century Palestine and Israel), 7:37.

100 "Makhṣuṣūn bi-șina'a al-yad wa-l-ḥidhq fī 'amal al-țuraf wa-l-mulaḥ”: al-Tha'ālibī, Kitāb Lațā'if al-Ma'ārif, 220 (for Bosworth's English translation, see Book of Curious and Entertaining Information, 141).

I0I See a good overview of this literature and new work on the sixteenth century in Hwang Degenhardt, "Cracking the Mysteries of 'China." 
assemblage of any given site in the Middle East at a given period. Yet these material sources privilege economic, technological, and design perspectives and cannot tell the whole story of reception. In the 1950s, the German scholar Paul Kahle initiated the important task of combing Islamic texts for references to Chinese ceramics, but this enterprise has hardly progressed since, ${ }^{102}$ and this type of discursive historiography remains absent from current surveys of the topic. ${ }^{103}$ Legal queries and halakhic opinions, such as those discussed here, constitute an important addition to this corpus and open new avenues for writing a history of the reception of Chinese ceramics that does not begin in 1500, nor center on Europe.

102 See Kahle's seminal "Chinese Porcelain in the Lands of Islam" and "Chinese Porcelain in the Lands of Islam -Supplement." Milwright's "Pottery in the Written Sources" is a rare exception among later scholarship; while not specifically focused on Chinese imports, he demonstrates the wealth of textual references awaiting scholarly attention.

103 For broad panoramas of the global impact of Chinese ceramics. see Pierson, Transfer; and (with caution, since the author is a historian rather than a ceramic specialist) Finlay's Pilgrim Art. A recent thematic issue on Chinese ceramics also provides a useful overview of recent scholarship: Journal of World History 23.1 (2012). 


\section{Bibliography}

\section{Primary Sources}

Akhbār al-Ṣin wa-l-Hind. Edited and translated by Jean Sauvaget as Relation de la Chine et de l'Inde. Redigée en 851. Paris: Société d'Édition "Les Belles Lettres," 1948.

Avot de-Rabbi Natan. Edited by Solomon Schechter. Vienna, 1887; repr. New York: Feldheim, 1967.

al-Bīrūnī, Muḥammad ibn Aḥmad. Kitāb al-Jamāhir fì Ma'rifat al-Jawāhir. Edited by Yusuf al-Hadi. Teheran: Sharika al-Nashr al-'Alami wa al-Thaqafi, 1995.

—_. Kitāb al-Jamāhir fĩ Ma'rifat al-Jawāhir. Translated by Hakim Mohammad said as Al-Beruni's Book on Mineralogy. The Book Most Comprehensive in Knowledge on Precious Stones. Islamabad: Pakistan Hijra Council, 1989.

al-Fasi, Isaac b. Jacob. Halakhot Rabati. Published in facsimile with an English introduction by Shamma Friedman. 2 vols. Jerusalem: Makor, 1974.

Ha-Levi of Bonn, Eliezer b. Joel. Sefer Ra'avyah. Edited by Avigdor Aptowitzer. 2 vols. Jerusalem: Mekize Nirdamim, 1964.

Ibn Abi Zimra. She'elot u-teshuvot ha-Radbaz. Edited by David b. Solomon. New York: A.Y. Friedman, 1990.

Ibn al-Zubayr. Kitāb al-Hadāyā wa-l-Tuhaf. Transated by Ghada Hijjawi Qaddumi as Book of Gifts and Rarities. Cambridge, MA: Harvard University Press, 1996.

Maimonides, Moses. Mishneh Torah. Edited by Shabse Frankel et al. 15 vols. Bene Barak: Hotzaat Shabse Frankel, 1975-2001.

al-Muqaddasī, Muḥammad ibn Aḥmad. Kitāb Aḥsan al-Taqāsim fì Ma'rifat al-Aqalīm. Translated by Basil Anthony Collins as The Best Divisions for Knowledge of the Regions. Reading: Garnet, 1994.

—. Kitāb Ahsan al-Taqāsim fì Ma'rifat al-Aqalīm. Edited by M. J. de Goeje as Descriptio Imperii Moslemici. Leiden: Brill, 1906.

Talmud Bavli. Jerusalem: Tal-Man, 1981.

al-Tha'ālibī, 'Abd al-Malik ibn Muḥammad. Kitāb Lațā'if al-Ma'ārif. Edited by Ibrahim Abyari and Hasan Kamil Sayrafi. Cairo: Dar Ihya' al-Kutub al-'Arabiya, 1960.

— Kitāb Latā'if al-Ma'ārif. Translated by C. E. Bosworth as The Book of Curious and Entertaining Information. Edinburgh: Edinburgh University Press, 1968.

Weiss, Isaac Jacob. Liquțey Teshuvot Minhat Yiṣhaq. Jerusalem: Minhat Yișhaq, 1995.

Waldenberg, Eliezer Yehuda. She'elot u-Teshuvot Șiș Eli`ezer. Jerusalem: A.Y. Waldenberg, 1984. 


\section{Secondary Sources}

Allen, Wayne. "Kashering China." In Perspectives on Jewish Law and Contemporary Issues, 147-51. Bloomington, IN: Trafford Publishing, 2011.

Bielenstein, Hans. Diplomacy and Trade in the Chinese World, 589-1276. Leiden: Brill, 2005.

Bongianino, Umberto. "'And their Figures and Colours Should Be Different.' Incised and Carved Glazed Wares from Fustāt (9th-12th century) in the Martin Collection (International Museum of Ceramics in Faenza)-Part I." Faenza 2 (2014): 28-48.

Botticini, Maristella, and Zvi Eckstein. The Chosen Few: How Education Shaped Jewish History, 70-1492. Princeton: Princeton University Press, 2012.

Bramoullé, David. "The Fatimids and the Red Sea (969-1171)." In Navigated Spaces, Connected Places, Proceedings of Red Sea Project V Held at the University of Exeter, 16-19 September 2010, edited by Dionisius A. Agius, John P. Cooper, Athena Trakadas and Chiara Zazzaro, 127-36. Oxford: Archaeopress, 2012.

Burke, Katherine Strange. Archaeological Texts and Contexts on the Red Sea: The Sheikh's House at Quseir Al-Qadim. PhD diss., University of Chicago, 2007.

Carswell, John, Siran Deraniyagala, and Alan Graham. Mantai: City by the Sea. Aichwald: Linden Soft, 2013.

Chaffee, John. "Diasporic Identities in the Historical Development of the Maritime Muslim Communities of Song-Yuan China." Journal of the Economic and Social History of the Orient, 49 (2006): 395-420.

Douglas, Mary. Purity and Danger: An Analysis of Concepts of Pollution and Taboo. London: Routledge, 2002.

Dupoizat, Marie-France. "The Ceramic Cargo of a Song Dynasty Junk Found in the Philippines and its Significance in the China-South East Asia Trade." In South East Asia \& China: Art, Interaction \& Commerce - Colloquies on Art \& Archaeology in Asia No. 17, edited by Rosemary Scott and John Guy, 205-24. London: Percival David Foundation, 1995.

Encyclopedia Judaica. 2nd ed. Detroit: Macmillan Reference, 2007.

Encyclopedia Talmudit. Jerusalem: Yad ha-Rav Herzog, 1996.

Finlay, Robert. The Pilgrim Art. Cultures of Porcelain in World History. Los Angeles: University of California Press, 2010.

Flood, Finbar Barry. Islam and Image: Polemics, Theology, and Modernity. Forthcoming.

François, Veronique. "La porcelaine de Chine à Byzance et dans l'Orient chrétien: une absence remarquable." Taoci 4 (2005): 67-73.

Freidenreich, David M. Foreigners and Their Food: Constructing Otherness in Jewish, Christian, and Islamic Law. Berkeley: University of California Press, 2011. 
Friedman, Mordechai A. Halfon ve-Yehuda ha-Levi. Le-qorotehem shel soher maskil u-meshorrer dagul 'al pi te'udot Genizat Qahir: Sefer Hodu IV/A. (Halfon and Judah Ha-Levi. The Lives of a Merchant Scholar and a Poet Laureate According to the Cairo Geniza Documents, India Book IV/A). Jerusalem: Ben-Zvi Institute and The Rabbi David Moshe and Amalia Rosen Foundation, 2013.

_ _ "Harhaqat ha-nida ve-ha-minut eșel ha-ge’onim, ha-Rambam, u-veno Avraham 'al pi kitvei Genizat Qahir," (Menstrual Impurity and Sectarianism in the Writings of the Geonim and of Moses and Abraham Maimonides.) Maimonidean Studies 1 (1990): 1-20.

_ . "Shne qeț'aim mi-sefer ha-ma'asim li-vene Ereș Yisrael." (Two Sections from the Book of Acts of the People of the Land of Israel.) Sinai 74 (1973): 14-36.

Ghabin, Ahmad. Hisba: Arts and Craft in Islam. Wiesbaden: Otto Harrasowitz, 2009.

Goitein, S. D. Letters of Medieval Jewish Traders. Translated from the Arabic with Introductions and Notes. Princeton: Princeton University Press, 1973.

—. A Mediterranean Society; the Jewish Communities of the Arab World as Portrayed in the Documents of the Cairo Geniza. 6 vols. Gustave E. Von Grunebaum Center for Near Eastern Studies. Berkeley: University of California Press, 1967-93.

—_. "The Stern Religion.” In Sefer Dinaburg, edited by Y. Baer, J. Gutmann, and M. Schwabe, 151-64. Jerusalem: Qiryat Sefer, 1949.

Goitein, S. D., and Mordechai A. Friedman. Avraham ben Yiju: Soḥer ve-yașran beHodu: Sefer Hodu III. (Abraham Ben Yiju: India Trader and Manufacturer. India Book III). Jerusalem: Ben-Zvi Institute and The Rabbi David Moshe and Amalia Rosen Foundation, 2010.

—. Halfon ha-soher ha-maskil ve-ha-nose'a ha-gadol: Sefer Hodu IV/B. (Halfon the Traveling Merchant Scholar: Cairo Geniza Documents: India Book IV/B). 2 vols. Jerusalem: Ben-Zvi Institute and the Rabbi David Moshe and Amalia Rosen Foundation, 2013.

—. India Traders of the Middle Ages: Documents from the Cairo Geniza ("India Book"). Leiden: Brill, 2008.

— . Mạ̣mun ha-Nagid Ereș Teiman ve-soher Hodu: Sefer Hodu II. (Maḍmūn Nagid of Yemen and the India Trade: India Book II). Cairo Geniza Documents. Jerusalem: Ben-Zvi Institute and the Rabbi David Moshe and Amalia Rosen Foundation, 2010.

Gray, Basil. "The Export of Chinese Porcelains to the Islamic World. Some Reflections on its Significance for Islamic Art, before 1400." Transactions of the Oriental Ceramic Society 41 (1975-77): 231-61.

Grossmark, Tziona. “'And He Decreed that Glassware is Susceptible to Becoming Unclean': The Application of the Laws of Ritual Purity to Glassware Reconsidered." Jewish Studies Quarterly 17 (2010): 191-212. 
Guy, John. "Rare and Strange Goods: International Trade in Ninth-Century Asia." In Shipwrecked: Tang Treasures and Monsoon Winds, edited by Regina Krahl et al., 19-34. Washington, DC: Smithsonian Institution, 2010.

Gyllensvard, B. "Recent Finds of Chinese Ceramics at Fostat." Bulletin of the Museum of Far Eastern Antiquities 45 (1973): 99-119; 47 (1975): 93-117.

Halevi, Leor. Muhammad's Grave: Death Rites and the Making of Islamic Society. New York: Columbia University Press, 2007.

Hallet, Jessica. "Pearl Cups Like the Moon: The Abbasid Reception of Chinese Ceramics." In Shipwrecked: Tang Treasures and Monsoon Winds, edited by Regina Krahl, John Guy, Julian Raby and J. Keith Wilson, 75-81. Washington, DC: Smithsonian Institution, 2010.

Hardy-Guilbert, Claire, and Axelle Rougeulle. "Al-Shihr and the Southern Coast of the Yemen: Preliminary Notes on the French Archaeological Expedition, 1995." Proceedings of the Seminar for Arabian Studies 27 (1997): 129-40.

—. "Archaeological Research into the Islamic Period in Yemen: Preliminary Notes on the French Expedition, 1993." Proceedings of the Seminar for Arabian Studies 25 (1995): 29-44.

Heng, Derek. "Shipping, Customs Procedures, and the Foreign Community: The 'Pingzhou ketan' on Aspects of Guangzhou's Maritime Economy in the Late Eleventh Century." Journal of Song-Yuan Studies 38 (2008): 1-38.

Ho, Chuimei. "The Ceramic Boom in Minnan." In The Emporium of the World: Maritime Quanzhou, 1000-1400, edited by A. Schottenhammer, 237-81. Leiden: Brill, 2001.

Hsueh-Man, Shen. "Luxury or Necessity: Glassware in Sarīra Relic Pagodas of the Tang and Northern Song Periods." In Chinese Glass: Archaeological Studies on the Uses and Social Context of Glass Artefacts from the Warring States to the Northern Song Period (Fifth Century B.C. to Twelfth Century A.D.), edited by Cecilia Braghin, 71-110. Florence: Olschki, 2002.

Hwang Degenhardt, Jane. "Cracking the Mysteries of 'China': China(ware) in the Early Modern Imagination." Studies in Philology 110 (2013): 133-68.

Jastrow, Marcus. A Dictionary of the Targumim, the Talmud Babli and Yerushalmi, and the Midrashic Literature. New York: Judaica Press, 1992.

Kahle, P. “Chinese Porcelain in the Lands of Islam.” In Opera Minora von Paul Kahle, 326-50. Leiden: Brill, 1956.

_ . "Chinese Porcelain in the Lands of Islam - Supplement." In Opera Minora von Paul Kahle, 351-61. Leiden: Brill, 1956.

Kana'an, Ruba. "The de Jure 'Artist' of the Bobrinski Bucket: Production and Patronage of Metalwork in pre-Mongol Khurasan and Transoxiana." Islamic Law and Society 16, no. 2 (2009): 175-201. 
— . "Patron and Craftsman of the Freer Mosul Ewer of 1232: A Historical and Legal Interpretation of the Roles of Tilmidh and Ghulam in Islamic Metalwork." Ars Orientalis 42 (2012): 67-78.

Kay, H. C., ed. Yaman: Its Early Medieval History. Mansfield Center, CT: Martino, 2005. Kerr, Rose. Song Dynasty Ceramics. London: Victoria and Albert Museum, 2004.

Kessler, Adam T. Song Blue and White Porcelain on the Silk Road. Leiden: Brill, 2012. King, Geoffrey, and Christina Tonghini. A Survey of the Islamic Sites near Aden and in the Abyan District of Yemen. London: School of Oriental and African Studies, 1996.

Krahl, Regina. "Chinese Ceramics in the Late Tang Dynasty." In Shipwrecked: Tang Treasures and Monsoon Winds, edited by Regina Krahl, John Guy, Julian Raby and J. Keith Wilson, 45-74. Washington, DC: Smithsonian Institution, 2010.

—_. "White Wares of Northern China." In Shipwrecked: Tang Treasures and Monsoon Winds, edited by Regina Krahl, John Guy, Julian Raby and J. Keith Wilson, 200-07. Washington, DC: Smithsonian Institution, 2010.

Krahl, Regina, John Guy, Julian Raby and J. Keith Wilson, eds. Shipwrecked: Tang Treasures and Monsoon Winds. Washington, DC: Smithsonian Institution, 2010.

Lambourn, Elizabeth. Abraham's Luggage: A Social Life of Things in the Medieval Indian Ocean World. Cambridge: Cambridge University Press. Forthcoming.

Lane, Arthur. Early Islamic Pottery: Mesopotamia, Egypt and Persia. London: Faber and Faber, 1947.

—. "Sung Wares and the Saljuq Pottery of Persia." Transactions of the Oriental Ceramic Society 22 (1946-47): 19-30.

Lane, Arthur, and R. B. Serjeant. "Pottery and Glass Fragments from the Aden Littoral, with Historical Notes." Journal of the Royal Asiatic Society of Great Britain and Ireland 2 (1948): 108-33.

Li, De-Jin. "Chinese Export Porcelain in the VIII-XIV Centuries." In UNESCO Maritime Route of Silk Roads - Nara Symposium '91 - Report, 102-04. Nara: Nara International Foundation, 1993.

Margariti, Roxani E. Aden and the Indian Ocean Trade: 150 Years in the Life of a Medieval Arabian Port. Chapel Hill: University of North Carolina Press, 2007.

Margulies, Mordecai. Hilkhot Ereș Yisrael min ha-Geniza. (Laws of the Land of Israel from the Geniza). Mosad ha-Rav Quq, 1973.

Mason, R. B. "Medieval Egyptian Lustre-painted and Associated Wares: Typology in a Multidisciplinary Study." Journal of the American Research Center in Egypt 34 (1997): 201-42.

- Shine Like the Sun: Lustre-Painted and Associated Pottery from the Medieval Middle East. Costa Mesa, CA: Mazda, 2004. 
Miksic, John N., ed. Southeast Asian Ceramics: New Light on Old Pottery. Singapore: Southeast Asian Ceramic Society, 2009.

Mikami, T. "China and Egypt: Fustat." Transactions of the Oriental Ceramic Society 45 (1980-81): 67-87.

Milwright, Marcus. "Modest Luxuries: Decorated Lead-Glazed Pottery in the South of Bilad al-Sham (Thirteenth and Fourteenth Centuries)." Muqarnas 20 (2003): 85-111.

— . "Pottery in the Written Sources of the Ayyubid-Mamluk Period (c. 567-923/ 1171-1517)." Bulletin of the School of Oriental and African Studies 62 (1999): 504-18.

Needham, Joseph, Rose Kerr, and Nigel Wood. Science and Civilization in China. Vol. 5, Chemistry and Chemical Technology; Part 12, Ceramic Technology. Cambridge: Cambridge University Press, 2004.

Neusner, J. "Purity and Impurity in Judaism." In The Encyclopaedia of Judaism, edited by Jacob Neusner, Alan J. Avery-Peck, and William Scott Green, 3:1109-23. Leiden: Brill, 2000.

Newman, Hillel I. Ha-Ma'asim li-vene Ereș Yisrael. ("Acts" of the People of the Land of Israel). Jerusalem: Yad Ben-Șevi, 2011.

Peng, Shifan ed. Song yuan jinian qingbai ci. (Dated Qingbai Wares of the Song and Yuan Dynasties). Hong Kong: Cheng Leng Foundation, 1998.

Pierson, Stacey. "Industrial Ceramics in China: Ceramic Production at Jingdezhen from the 10th to the 16th Century." In Lost at Sea: The Strange Route of the Lena Shoal Junk, edited by Franck Goddio and Gabriel Casal, 59-69. Periplus: London, 2002.

- ed. Qingbai Ware: Chinese Porcelain of the Song and Yuan Dynasties. London: Percival David Foundation, 2002.

- ed. Transfer: The Influence of China on World Ceramics. London: Percival David Foundation, 2009.

Pirazzoli-t’Serstevens, Michèle. "Une denrée recherchée: la céramique chinoise importée dans le golfe arabo-persique, IX ${ }^{\mathrm{e}}-\mathrm{XIV}^{\mathrm{e}}$ siècles." Mirabilia Asiatica 12 (2005): 69-88.

Rackman, Emmanuel, Michael Broyde, and Amy Lynne Fishkin. "Halakhah, Law in Judaism," Encyclopaedia of Judaism (Brill Online, 2012). [accessed August 17, 2012].

Rougeulle, Axelle. "Les céramiques à glaçure." In Sharma: un entrepôt de commerce médiéval sur la côte du Hadramawt (Yémen, ca. 980-1180), edited by Axelle Rougeulle, 237-75. Oxford: Archaeopress, 2015.

__. "Golfe persique et Mer Rouge: notes sur les routes de la céramique aux X-XII siècles." Taoci 4 (2005): 41-51. 
—. "Les importations de céramiques chinoises dans le golfe arabo-persique (VIII'-IX siècles)." Archéologie Islamique (1991): 5-46.

Schottenhammer, Angela. The Emporium of the World: Maritime Quanzhou, 1000-1400. Leiden: Brill, 2001.

Teo, Catherine. “Qingbai Ware for Export.” In Qingbai Ware: Chinese Porcelain of the Song and Yuan Dynasties, edited by Stacey Pierson, 244-51. London: Percival David Foundation, 2002.

Twersky, Isadore. Introduction to the Code of Maimonides (Mishneh Torah). New Haven: Yale University Press, 1980.

Walter, Moshe. "Can Porcelain be Kashered?" Journal of Halacha and Contemporary Society 52 (2006): 110-23.

Watson, Oliver. "Chinese-Iranian Relations XI. Mutual Influence of Chinese and Persian Ceramics," Encyclopedia Iranica 5 (1991) <http://www.iranicaonline. org/articles/chinese-iranian-xi [accessed April 9, 2015].

—_. "Fritware: Fatimid Egypt or Seljuq Iran?" In L'Egypte Fatimide son art et son histoire, edited by M. Barrucand, 299-307. Paris: Presses de l'Université de Paris-Sorbonne, 1999.

Whitcomb, Donald. "A Fatimid Residence at Aqaba, Jordan." Annual of the Department of Antiquities of Jordan 32 (1988): 207-24.

Whitehouse, David. “Chinese Porcelain in Medieval Europe." Medieval Archaeology 16 (1973): 78-63.

Yuba, Tadanori. "Chinese Ceramics Found at al-Fustat, Cairo, 9th to 16th Century." Taoci 4 (2005), 87-95.

_ . "Chinese Porcelain from Fustat based on Research from 1998-2001." Transactions of The Oriental Ceramic Society 76 (2011-12): 1-18.

Zhao, Bing. "La céramique chinoise à Sharma: pour un essai d'étude d'approche typo-chronologique et spatiale." In Sharma: un entrepôt de commerce médiéval sur la côte du Hadramawt (Yémen, ca. 980-1180), edited by Axelle Rougeulle, 277-321. Oxford: Archaeopress, 2015.

__ .Global Trade and Swahili Cosmopolitan Material Culture: Chinese-style Ceramic Shards from Sanje ya Kati and Songo Mnara (Kilwa, Tanzania)." Journal of World History 23 (2012): 41-85.

_ . "L'importation de la céramique chinoise à Sharma (Hadramaout) au Yémen." In Ports et commerce en Islam médiéval, entre Asie, Afrique et Arabie, special issue, Annales Islamologiques 38 (2004): 255-84. 


\section{Acknowledgments}

Elizabeth Lambourn thanks the Leverhulme Trust for funding her Major Research Fellowship during 2011-13; the present article is a direct outcome of research conducted during that period as part of her project on West Asia in the Indian Ocean, 500-1500 CE. She is also extremely grateful to Jessica Harrison-Hall (Curator of Chinese Ceramics and the Sir Percival David Collection at the British Museum) for including her in the British Museum Study Day on Chinese Qingbai Ceramics and Their Contexts (May 15, 2015). The handling session was invaluable and discussions with the specialists in Chinese ceramics present at this event have been highly influential on the writing of the final draft of this article. Special thanks go to Rosemary E. Scott (International Academic Director of Asian Art at Christie's), who generously shared a large number of references from Chinese and other specialist sources; her contributions are acknowledged in the footnotes. Thanks, too, to Li Baoping (Senior International Researcher at Sotheby's) for his engagement with the ideas presented here and for sharing some of his recent publications and suggesting additional bibliographic material. In Paris, Zhao Bing of the Collège de France has been more than generous in reading and commenting on the final draft as well as sharing the final proofs of her article "La céramique chinoise à Sharma." Axelle Rougeulle also shared her piece on "Les céramiques à glaçure" and kindly answered my queries about the rather late development of glazed ceramic production in the Yemen. Melanie Gibson generously commented on an early draft of this article, shared some of the less accessible articles found in the bibliography, and generally helped demystify the scholarship on the Middle East's response to Chinese ceramics.

Phil Lieberman would also like to thank the Leverhulme Trust, as well as Rabbi Joshua Barton of Nashville, Tennessee, for his assistance in translating difficult passages in the rabbinic literature related to the subject matter of this article.

Both authors wish to thank the anonymous peer reviewers for their generous and perceptive comments. Any errors are, of course, the authors' own. 
Phillip Ackerman-Lieberman (phil.lieberman@vanderbilt.edu) is Associate Professor of Jewish Studies and Law, Associate Professor of Religious Studies, and Affiliated Associate Professor of Islamic Studies and History, at Vanderbilt University in Nashville, Tennessee. He is a social, economic, and legal historian of the medieval Islamic world. His current project examines Jewish urbanization under the early Abbasids and subsequent Jewish migration to the emerging communities of the Islamic Mediterranean. His 2014 book, The Business of Identity (Stanford University Press) was a finalist for the National Jewish Book Award. He also served as one of the editors of The Encyclopedia of Jews in the Islamic World (Brill, 2010).

Elizabeth Lambourn (elambourn@dmu.ac.uk) is Reader in South Asian and Indian Ocean Studies at De Montfort University in the United Kingdom, where she works on diverse aspects of mobility in the precolonial Indian Ocean world. Coming to history from a background in the study of material culture, her research is particularly focused on Indian Ocean materialities and the identification and study of new material archives. Her monograph, Abraham's Luggage: A Social Life of Things in the Medieval Indian Ocean World, will be published with Cambridge University Press in 2017.

Abstract This article focuses on a set of legal questions about șinī vessels (literally, "Chinese" vessels) sent from the Jewish community in Aden to Fustat (Old Cairo) in the mid-1130s CE and now preserved among the Cairo Geniza holdings in Cambridge University Library. This is the earliest dated and localized query about the status of șini vessels with respect to the Jewish law of vessels used for food consumption. Our analysis of these queries suggests that their phrasing and timing can be linked to the contemporaneous appearance in the Yemen of a new type of Chinese ceramic ware, qingbai, which confounded and destabilized the material taxonomies underpinning rabbinic Judaism. Marshalling evidence from contemporary Jewish legal compendia and other writings produced in this milieu, our discussion substantially advances interpretive angles first suggested by S. D. Goitein and Mordechai A. Friedman to examine the efforts of Adeni Jews to place this Chinese ceramic fabric among already legislated substances, notably the "neighboring" substances of glass and earthenware, in order to derive clear rules for the proper use and purification of vessels manufactured from it.

Keywords Aden, Yemen, China, Indian Ocean, 'India Book', Cairo Geniza, Judaism, medieval, Middle Ages, ceramic, porcelain, qingbai, glass, earthenware, halakha, purity, purification, pollution, kosher, koshering, menstruation, material taxonomies, material culture. 